\title{
An overview of chromium removal techniques from tannery effluent
}

\author{
Md. Nur-E-Alam ${ }^{1,5} \cdot$ Md. Abu Sayid Mia ${ }^{2,5} \cdot$ Farid Ahmad $^{3}$ (D) $\cdot$ Md. Mafizur Rahman ${ }^{4}$
}

Received: 10 January 2020 / Accepted: 23 July 2020 / Published online: 9 August 2020

(c) The Author(s) 2020

\begin{abstract}
Industrial activities that consume water generate wastewater as a by-product of processing which introduces various contaminants such as heavy metals into the neighbouring water bodies that creates adverse effects on the surrounding environment. Tannery industry releases more toxic effluent than most industries, which directly and indirectly exerts stress on various ecosystems. The heavy metal chromium ( $\mathrm{Cr}$ ), one of the pollutants found in tannery effluent, is very much detrimental to human health, animals, and plants. Conventional physico-chemical and biological processes can remove this heavy metal in considerable amounts. Recently, various applications of advanced technologies such as membrane technology, electrocoagulation, ion exchange, and electrodialysis for tannery wastewater have been growing due to their relative advantages over other technologies in terms of sustainability. This paper represents the review of various available techniques as well as represents a case study of chromium removal from tannery effluent by a low-cost absorbent.
\end{abstract}

Keywords Tanning $\cdot$ Chromium removal $\cdot$ Low-cost adsorbents $\cdot$ Tannery effluent $\cdot$ Environmental pollution

\section{Introduction}

Water in the Earth is analogous to blood in the human body. Without water, Earth may be considered as an another planet, a sterile, desolate, grey hunk of orbiting

Md. Nur-E-Alam

nalam1980@yahoo.com

Md. Abu Sayid Mia

emsayid@gmail.com

Farid Ahmad

ahmadfarid@iat.buet.ac.bd

Md. Mafizur Rahman

mafizur@gmail.com

1 Leather Research Institute (LRI), Bangladesh Council of Scientific and Industrial Research (BCSIR),

1350 Savar, Dhaka, Bangladesh

2 Institute of Leather Engineering and Technology, University of Dhaka, 1209 Dhaka, Bangladesh

3 Institute of Appropriate Technology, Bangladesh University of Engineering and Technology (BUET), 1000 Dhaka, Bangladesh

4 Department of Civil Engineering, Bangladesh University of Engineering and Technology (BUET), 1000 Dhaka, Bangladesh

5 Applied Chemistry and Chemical Engineering, University of Dhaka, 1000 Dhaka, Bangladesh rock (Spellman 2017). In the name of urbanization and industrialization, people on Earth are polluting the Earth's blood that is water. Various industrial processing are the main sources of water pollution, and it may vary extensively with the nature of industry. Wastewaters from industries generally include processing waste from the manufacturing unit, sanitary waste of employees, water discharged from washing factory floor and relatively uncontaminated heating and cooling water (Emongor et al. 2005). Treatment of wastewater for removing toxic metal pollutant contents is of great concern as these metals create a great threat to people's and animal's health. Among them, chromium is one of the familiar contaminants which gains importance owing to its highly toxic character even at a very low concentration. In addition, water contamination by chromium $(\mathrm{Cr})$ has drawn greater attention in the present context of global ecology as this metal has found its extensive use in textile industries, electroplating, leather processing, metal finishing, and chromium preparation. Chromium exists in oxidation states of $\mathrm{Cr}(\mathrm{II}), \mathrm{Cr}(\mathrm{III})$ and $\mathrm{Cr}(\mathrm{VI})$ where hexavalent form of $\mathrm{Cr}$ is 500 times more toxic than the trivalent one. This $\mathrm{Cr}(\mathrm{VI})$ is a carcinogenic agent which can cause health risks for humans. Its toxicity may damage human organs including kidney and liver as well as can cause dermatitis and gastrointestinal ulcers. The trivalent chromium is more stable and sometimes is 
essential for mammals in trace amount and comparatively immobile in the aquatic system owing to its low water solubility. Apart from surface water pollution, groundwaters are also contaminated by $\mathrm{Cr}$-related industrial activities (Belay 2010; Swathanthra and Rao 2014; Kowalski 1994; Dokken 1999). For this reason, hard and fast environmental regulations exist in many countries for controlling the discharge concentration limit of chromium to the environment. Several treatment procedures such as adsorption, chemical precipitation, electrocoagulation, ion exchange, electrodialysis, and membrane separation are available for removal of $\mathrm{Cr}$ from wastewater (Fathima et al. 2005). Among these, chemical precipitation is the common way for the removal. Commonly used chemical precipitators are sodium hydroxide, calcium hydroxide, magnesium oxide, or calcium magnesium carbonate. Parameters or factors that are affecting the precipitation including the type of precipitation agent, $\mathrm{pH}$, speed or agitation, sludge volume, time of mixing, and complexing agents (Abdulla et al. 2010; Kocaoba and Akcin 2002). Again, advanced treatment techniques, such as ion exchange, reverse osmosis, electrocoagulation, membrane filtration, and electrodialysis are effective for removing $\mathrm{Cr}(\mathrm{VI})$, but these are expensive and produce concentrated wastes that require subsequent treatment and disposal (Komori et al. 1990). Biological treatment may give a suitable means for $\mathrm{Cr}(\mathrm{VI})$ removal from wastewater. Various fungal and bacterial species were reported for chromium bioremoval. Actinomycetes, Streptomyces rimosus and Streptomyces griseus showed promising chromium removal from wastewater (Nerenberg and Rittmann 2004; Lovley and Coates 2003; Polti et al. 2007; Poopal and Laxman 2009). Alternately, some low-cost agriculture wastes such as chitosan (Yasmeen et al. 2016), rice husk (Xavier et al. 2013), waste tea leaves (Nur-E-Alam et al. 2018), neem leaves (Gopalakrishnan et al. 2013), coconut shell, orange peel (Amir et al. 2017; Stoller et al. 2017), banana rachis (Payel and Sarker 2018), watermelon rind (Stoller et al. 2017), pomegranate husk (El Nemr 2007), sawdust (Prado et al. 2010), etc., have adsorption potential to remove $\mathrm{Cr}$ from wastewater particularly tannery effluent.

In recent years, the strong environmental law compels industry to invent sustainable technologies to bring down the concentration of hazardous metal ions below the discharge limits. For that, advanced wastewater treatment like membrane filtration (Chaudry et al. 1998; Hafez et al. 2002; Kulkarni et al. 2007), electrocoagulation (Gao et al. 2005; Babu et al. 2007), electro-flotation (Babu et al. 2007), electro-oxidation (Ouejhani et al. 2008; Panizza and Cerisola 2016), ion exchange (Panizza and Cerisola 2016; Sahu et al. 2009), electrodialysis (Deghles and Kurt 2016; Lambert et al. 2006), etc., have gained importance for removal of $\mathrm{Cr}$ from tannery wastewater.

\section{Tanning process}

Leather tanning is an ancient trade that dates further back than husbandry, textile, art, music, and even the evolution of writing. Even in ancient cultures, tanning process maintained desirable properties of leather for making useful articles, particularly shoes, clothing, and leather goods. Leather manufacturing process depends greatly on the byproduct of the meat industry that slaughters animals primarily for the meat (Thorstensen 1999). Leather tanning is defined as a process of converting putrescible outer coverings of animals to non-putrescible leathers with definite physical, chemical, and biological properties so that they can be used in our daily life and industries (Dutta 1999). This is a multistep lengthy process, involving a number of chemicals, salts, and other auxiliaries. Operations carried out in the beam house, tanyard, and post-tanning areas are frequently referred to as wet processes, as they are carried out in processing vessels such as drums. Following posttanning, leather is subjected to dry finishing operations. Processes employed in each of the above stages depend on the raw materials used and the desired final products. Therefore, the environmental impacts incurred from discharge wastewater contents vary from tannery to tannery. Figure 1 shows the various processing steps of leather tanning (Rydin et al. 2013).

\section{Tanning and environmental threats}

Some industrial activities generate pollutants that adversely affect the entire environments. These pollutants present in wastewater at different concentrations enter into the environment directly or indirectly. That is why treatment of these wastewaters is major areas of concern, and these wastewaters may vary extensively with the type of industry (Emongor et al. 2005). Wastewaters released from tanneries are ranked as the biggest polluters among all industrial wastewaters (Shen 1999). Among the various tanning systems, chrome and vegetable tanning are popular all over the world. Today, $80-90 \%$ of leathers produced in the world are Chrome-tanned leather. Chromium was first discovered by French chemist Nicolas Louis Vauquelin in 1780 in Paris (Chemicool 2012). Chrome tanning uses acids, various solution of chemicals, and salts including chromium sulphate to tan the hides and skins (Silvateam 2020). Chromium needed for chrome tanning is about $2 \%$ or more of the weight of the hides and skins, and the fixation of the chromium is about $60-70 \%$ only. Therefore, about $0.5 \mathrm{~kg}$ chromium may remain in the used tanning solutions per $1000 \mathrm{~kg}$ of hides tanned. This results in 


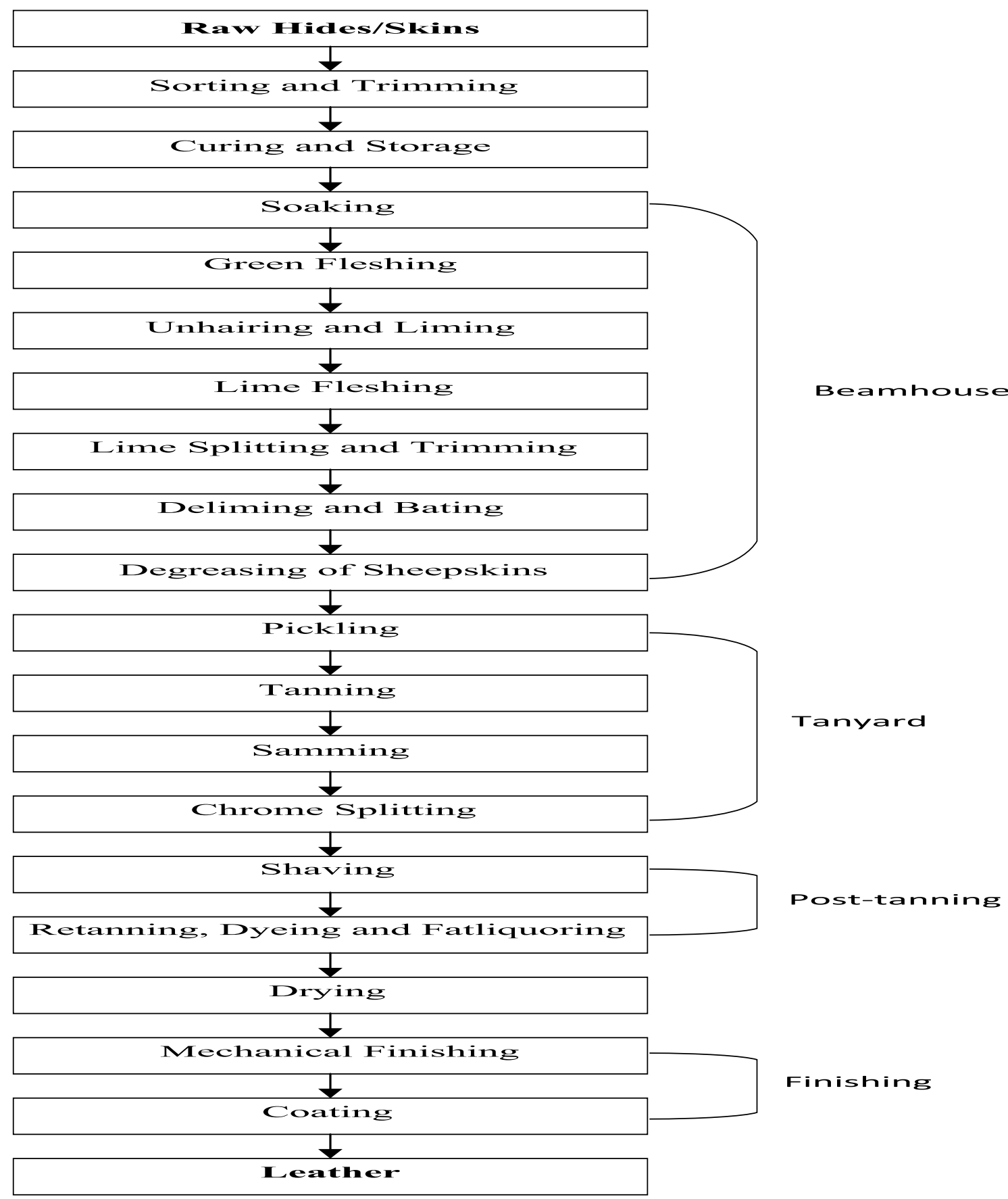

Fig. 1 Process steps in leather tanning (Rydin et al. 2013)

material loss as well as disturbance to ecological balance (Thorstensen 1999). Though the leather industries play a significant role in the national economy of many countries, these also create negative impacts on the country's total environment. The high concentration and low biodegradability of the pollutants present in tannery effluent is a major cause of serious environmental concern (Saxena et al. 2016). Following paragraphs very briefly describe the negative impacts of tannery wastes on environment and on human health.

\section{On the surface water}

Tannery effluents are characterized as high-coloured, foulsmelling, acidic, and alkaline liquor (Essays 2018). The disposals of these effluents into any surface water affect its 
quality in diverse ways. The high organic content interferes with the oxygen content of the receiving water. The alkaline and sulphide content jeopardize the aquatic life. Effluent contains hydrogen sulphide gas when mixed with receiving water, then this gas is liberated due to the lowering of $\mathrm{pH}$ value. This gas is so poisonous that its concentration of 800 parts per million parts of air may cause death to human being (Dutta 1999). Chromium (III) in wastewater despite its significantly less toxicity than $\mathrm{Cr}(\mathrm{VI})$ makes the aquatic environment toxic to the biota. Presences of lime, short hair, fleshing, etc., make the water cloudy, and the colouring substance alters the taste and odour. It also impedes the sunlight penetration, thus reducing the photosynthetic activity (Mwinyikione 2010). Oily substance affects the aeration of water and as an indirect effect threatens the survival of the aquatic life. COD and BOD values of the tannery effluent are much higher than that of the surface water quality guideline (Akan et al. 2009). Figure 2 shows the mixing of tannery wastes with surface water.

\section{On soil}

The fertility of soil is greatly affected from the pollution caused by disposed tannery effluent. Crops grown in this soil show delayed maturity and stunting (Mondol et al. 2017). Chamon et al. observed a reduction of rice production by $43.6 \%$ due to soil toxicity with the tannery heavy metals (Chamon et al. 2005). Usually, tannery solid wastes are dumped on the nearby tannery areas as shown in Fig. 3.

\section{On ground water}

Due to the dumping of untreated tannery wastes into the river, land, roadsides, agricultural fields, salts, and other chemicals percolate into the soil, thus polluting the groundwater. This affects the drinking water quality as well as

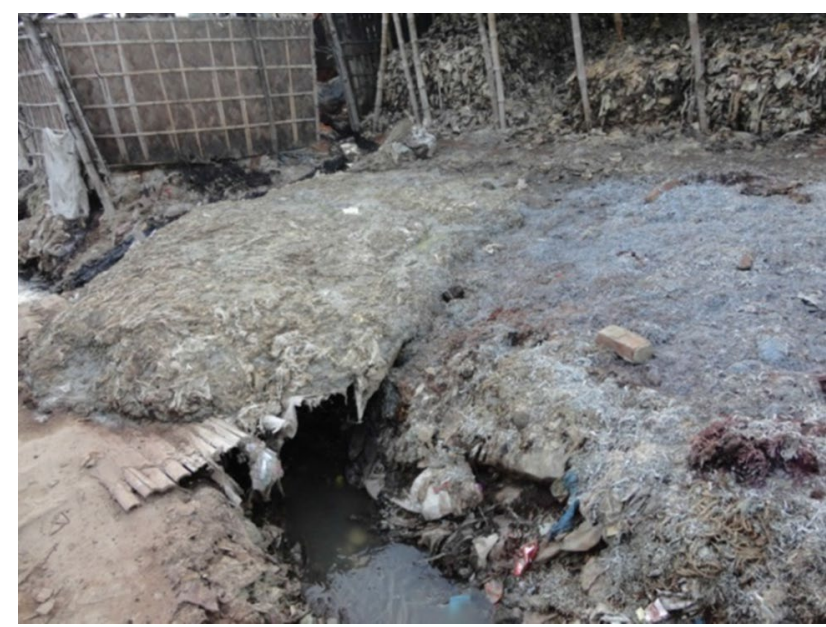

Fig. 2 Tannery wastes mixing with drain water (Authors)

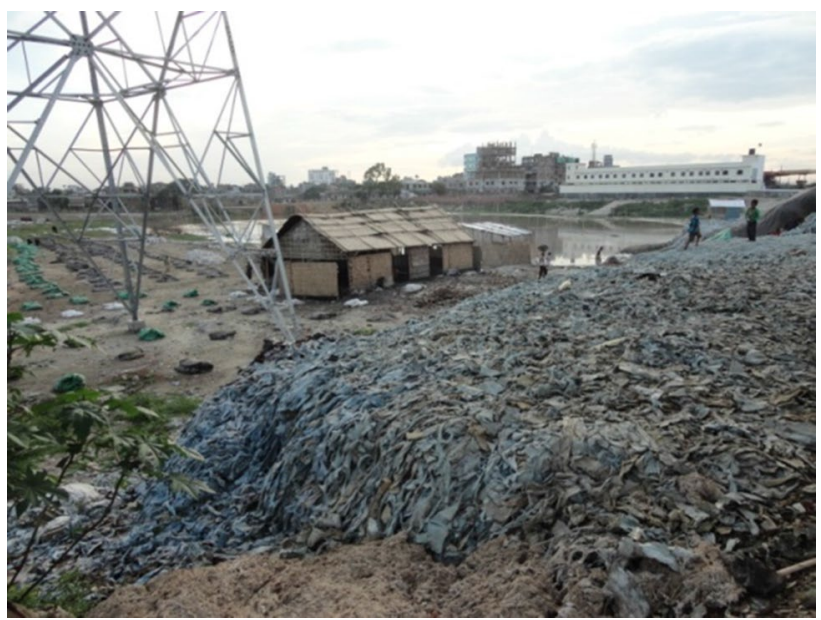

Fig. 3 Tannery wastes on land (Authors)

the irrigation system around the affected areas such as low crop production (Kankaria et al. 2011; Mondal et al. 2005). Groundwater may take a lengthy time to purify itself owing to its slow movement and out of contact with air (Jahan et al. 2015).

\section{On sewers}

Disposal of tannery wastes into the sewer causes the clogging of the sewers. The suspended solids like lime, hair, fleshing, etc., settles at the bottom of the sewer thus choking the water flow. Figure 4 shows the mixing of tannery effluent with sewer.

\section{On human health}

Unsafe working conditions of tanneries create occupational and health hazards. There are numerous general health problems that tannery workers face like skin and respiratory

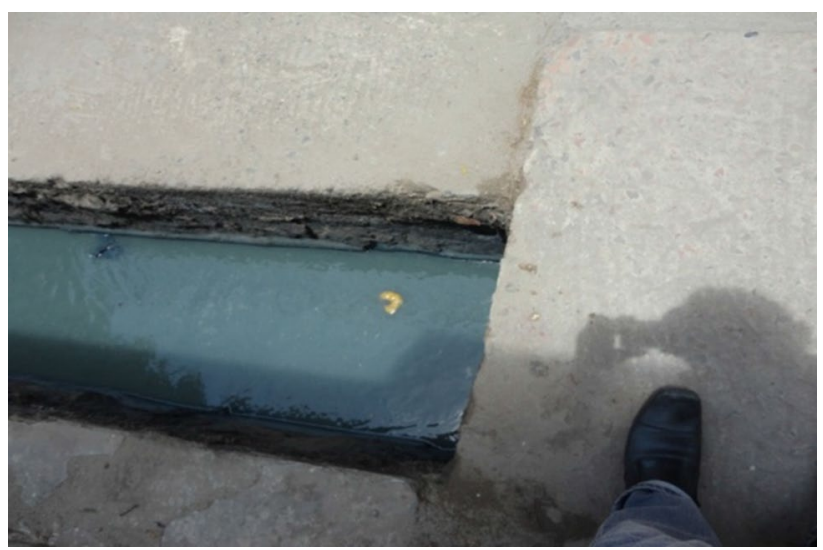

Fig. 4 Tannery effluent mixes with sewer (Authors)
1

لودينة الملاك عبدالعزيز

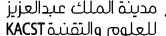


diseases, which are resulted from repeated exposure to hazardous chemicals (Das et al. 2015). Chromium that is not fixed by the hides and skins remains in the effluent as about $30-40 \%$ of the initial amount. Though Cr(III) is a necessary nutrient for the human body, there is no doubt that $\mathrm{Cr}(\mathrm{VI})$ compounds are acutely and chronically toxic. It can cause headache, dizziness, irritation of eyes, and skin, allergic reactions, damage to liver, kidney or nervous system or collapse lungs due to lack of oxygen (Belay 2010; Kankaria et al. 2011). According to Human Rights Watch, $90 \%$ of tannery employees die before the age of 50. Many workers die of cancer probably caused by exposure to toxic chemicals used for leather tanning (PETA 2019; Human Rights Watch 2012).

\section{On air}

Air pollutants such as hydrogen sulphide $\left(\mathrm{H}_{2} \mathrm{~S}\right)$, ammonia $\left(\mathrm{NH}_{3}\right)$, sulphur dioxide $\left(\mathrm{SO}_{2}\right)$, carbon dioxide $\left(\mathrm{CO}_{2}\right)$, fume of formic acid, chlorine $\left(\mathrm{Cl}_{2}\right)$, volatile organic compounds (VOCs), etc., are generated in different stages of leather processing that accumulate in the air to a degree that is harmful to living organism. Out of these both the $\mathrm{H}_{2} \mathrm{~S}$ and $\mathrm{NH}_{3}$ are very toxic gases. Bad odour also comes from the putrefying hides and skins. These pollutants returned to the earth's surface as fog or mist or acid rain which affects aquatic life, vegetation, and human health (Das et al. 2015; Hashem and Jor 2015; Panda et al. 2012). Exposure to $\mathrm{H}_{2} \mathrm{~S}$ gas, which has a characteristic rotten egg odour, may cause delirium, nausea, headaches, and disturbed equilibrium, convulsions, tremors, as well as skin and eye irritation. It causes many respiratory diseases (ATSDR 2014). Contaminants that are produced during the different steps of the leather tanning process are given in Table 1.

\section{Methods of chromium (Cr) removal from tannery wastewater}

Heavy metal contents of wastewater generated from diverse types of industries pose serious threats to the environment. Their concentration in the environment has increased to a dangerous level due to extensive industrial activities.
Massive amounts of solid and liquid wastes are thrown to the environment without any treatment. Metals whose density exceeds $5 \mathrm{~g}$ per cubic centimetre is regarded as heavy metals. Most of the elements fall into this group are highly water-soluble, toxic and carcinogenic agents (Gunatilake 2015a). Heavy metals in industrial effluent include lead, nickel, arsenic, chromium, and cadmium. Several physicochemical processes have been developed for the removal of heavy metals of industrial effluent (Singh and Gupta 2016). Chromium is extensively used in industrial activities like leather tanning, electroplating, stainless steel production, and wood preservatives making. Wastewaters produced from these industries containing $\mathrm{Cr}$ have harmful effects on the environment as well as to human health because $\mathrm{Cr}$ is well known for its carcinogenicity, mutagenicity, and teratogenicity in humans, animals, and plants (Saranraj and Sujitha 2013). In $\mathrm{Cr}$ tanning, only $60-70 \%$ of total chromium salts react with the hide and skin that is why about $30-40 \%$ of chromium remains in the solid and liquid wastes. Consequently, the removal and recovery of the chromium content of the tannery wastewaters are essential from the economic and environmental standpoint (Esmaeili et al. 2009). Brief descriptions of some of the removing processes of Chromium from wastewaters are presented below.

\section{Adsorption}

Adsorption is considered as a phase transfer process which is generally used to eliminate substances from various wastewaters and gases. It is a separation or purification technique that has been used for a very long time, and the heart of the adsorption process is usually the porous solid medium. Adsorption may be defined as the enrichment or accumulation of particles from the fluid phase on the surface of a solid or a liquid. There are mainly three distinct mechanisms for adsorption. These are steric, equilibrium, and kinetic mechanisms. Steric separation allows the molecules to enter having less pore diameter of the porous solid and excludes the larger molecules. In equilibrium mechanism, molecules having stronger adsorbing power are preferentially separated by the adsorbent. The kinetic mechanism is based on the different rates of diffusion of different molecules into the pore of the
Table 1 Chemical and gaseous contaminants produced at different stages of leather processing (Mwinyikione 2010)

\begin{tabular}{lll}
\hline Leather processing stage & Water pollutants & Air pollutants \\
\hline Soaking/liming & BOD, COD, SS, DS, sulphides & $\mathrm{H}_{2} \mathrm{~S}$ \\
Deliming and bating & BOD, COD, SS & $\mathrm{NH}_{3}$ \\
Degreasing & BOD, COD, DS & \\
Pickling/tanning & BOD, COD, DS, acids, salts & Acidic fumes \\
Retanning/bleaching/dyeing & Acids, salts, chrome, chlorinated, phenols & $\begin{array}{c}\text { Volatilized, } \\
\text { chlorinated, } \\
\text { phenolics }\end{array}$ \\
\hline
\end{tabular}


solid; thus, by controlling the time of exposure the fasterdiffusing molecules are preferentially separated by the solid (Worch 2012; Do 1998). For simplicity and cost-effectiveness, adsorption plays an important role in the treatment of wastewater (Malik et al. 2015). Surface area, $\mathrm{pH}$ of the solution, temperature, nature, dose of adsorbent, and interfering substances affect the adsorption process (Grassi et al. 2012). Many researchers treated chromium-loaded wastewaters by adsorption process with various adsorbents. Bansal et al. has carried out research on $\mathrm{Cr}(\mathrm{VI})$ removal from synthetic wastewater using agricultural waste of rice husk. Batch mode operation was carried out considering $\mathrm{pH}$, adsorbent dose, solution initial concentration, and contact time as operating parameters. Maximum $76.5 \% \mathrm{Cr}(\mathrm{VI})$ was removed at pH 2.0 with formaldehyde treated rice husk (Bansal et al. 2009). Fahim et al. investigated removal of $\mathrm{Cr}$ (III) from tannery effluent using low-cost activated carbon produced from sugar industry waste and could remove $98.86 \% \mathrm{Cr}$ (III) (Fahim et al. 2006). Birhanie et al. researched on pumice (volcanic rock) for removing $\mathrm{Cr}$ from tannery effluent and achieved 76\% Cr reduction (Birhanie et al. 2017). Sivakumar used rice husk silica powder as an adsorbent for removal of $\mathrm{Cr}(\mathrm{VI})$ from tannery effluent. At dose of $15 \mathrm{~g}$, the contact time of $150 \mathrm{~min}$, and $\mathrm{pH}$ of 4 , the study found a maximum $88.3 \% \mathrm{Cr}(\mathrm{VI})$ removal (Sivakumar 2015). Natural adsorbents such as clay, zeolites, peat moss, and chitin and agricultural wastes like neem bark, walnut shell, rice husk, spent tea waste, sugar industry waste, etc., are regarded as effective adsorbent for removing heavy metal like $\mathrm{Cr}, \mathrm{Pb}, \mathrm{Cd}$, $\mathrm{Cu}, \mathrm{Zn}$, etc., from various industrial wastewater (Tripathi and Rawat Ranjan 2015). Bark of Pinus sylvestris, a species of pine, was used by Alves et al. as adsorption agent of $\mathrm{Cr}$ (III) removal from tanning wastewater. The study shows that more than 90\% Cr removal was obtained at $\mathrm{pH} 4.5-5.0$ range (Margarida Alves et al. 1993). Payel et al. used banana rachis charcoal to uptake $\mathrm{Cr}$ from tannery wastewater. The study was performed against different operating parameters, e.g., contact time, dose, and $\mathrm{pH}$. The maximum $\mathrm{Cr}$ uptake was found $99.8 \%$ at $\mathrm{pH} 6.7,3 \mathrm{~g} / 75 \mathrm{ml}$ dose, and $15 \mathrm{~min}$ contact time (Payel and Sarker 2018). Removal of Cr(III) from artificial and real tannery effluent was investigated by Santosa et al. using chitin-humic acid as adsorbent (Santosa et al. 2008).

\section{Chemical precipitation}

Chemical precipitation is regarded as one of the established technology for heavy metals and other pollutants removal from wastewater owing to its simplicity and low cost. In this method, pollutants settle down as precipitates which then separated from the solution employing filtration, centrifugation, or other suitable methods. Coagulant as a precipitating agent causes the smaller particles suspended in solution to increase their particle size for settling down as sludge. Usually, hydroxide precipitant is commonly used for its low cost, simplicity, and ease of $\mathrm{pH}$ control. The conventional chemical precipitation techniques include sulphide precipitant and hydroxide precipitant (Gunatilake 2015a; Esmaeili et al. 2009; USEPA 2000). In hydroxide precipitation process, addition of coagulants such as iron salts, alum, and organic polymers can increase the removal quantity of heavy metals from wastewater (Fu and Wang 2011). Some common precipitants and their characteristics are shown in Table 2.

Chemical precipitation of chromium by calcium hydroxide $\left[\mathrm{Ca}(\mathrm{OH})_{2}\right]$, sodium hydroxide $(\mathrm{NaOH})$, magnesium oxide $(\mathrm{MgO})$, or calcium magnesium carbonate $\left[\mathrm{CaMg}\left(\mathrm{CO}_{3}\right)_{2}\right]$ is frequently practiced in many tanneries (Hintermeyer et al. 2008). Ramakrishnaiah and Prathima worked on the removal of $\mathrm{Cr}$ from synthetic wastewater using sodium hydroxide and calcium hydroxide combination at dose of $100 \mathrm{mg} / \mathrm{l}$ and $\mathrm{pH}$ 7. The study found the maximum percentage (99.7\%) of $\mathrm{Cr}$ removal and the sludge production minimal (Ramakrishnaiah and Prathima 2012). Minas et al. found better results using $\mathrm{MgO}$ as precipitating agent than $\mathrm{NaOH}$ and $\left.\left[\mathrm{Ca}(\mathrm{OH})_{2}\right)\right]$ at $\mathrm{pH} 9.8-10.3$. They recovered almost $30 \%$ $\mathrm{Cr}$ using concentrated sulphuric acid $\left(\mathrm{H}_{2} \mathrm{SO}_{4}\right)$ at about $\mathrm{pH}$ 2.8 , and this Cr could be mixed with $70 \%$ fresh basic chromium sufate (Minas et al. 2017). Abbas et al. investigated four precipitating agents such as $\mathrm{NaOH},\left[\mathrm{Ca}(\mathrm{OH})_{2}\right], \mathrm{MgO}$ and $\mathrm{Al}_{2}\left(\mathrm{SO}_{4}\right)_{3} \cdot 18 \mathrm{H}_{2} \mathrm{O}$ for the reduction of $\mathrm{Cr}$ from tannery effluent. The $\mathrm{Cr}$ removal by $\mathrm{MgO}$ and $\mathrm{Ca}(\mathrm{OH})_{2}$ combination showed better result than the others and also produced less amount of sludge (Abbas et al. 2010). Precipitators like $\mathrm{NaOH}, \mathrm{Ca}(\mathrm{OH})_{2}$, or $\mathrm{MgO}$ immobilize the heavy metals as their respective hydroxides. Barbooti et al. studied removal of various heavy metals such as chromium (III), copper (II), iron (III), lead (II), nickel (II), and cadmium (II) from

Table 2 Common precipitants and their characteristics (USEPA 2000)

\begin{tabular}{ll}
\hline Chemicals & Characteristic \\
\hline Alum & Alum is an off-white crystal which, when dissolved in water, produces acidic conditions \\
Ferric chloride & Ferric chloride $\left(\mathrm{FeCl}_{3}\right)$ is available in either dry (hydrate or anhydrous) or liquid form. The liquid form is usually \\
& $35-45 \% \mathrm{FeCl}_{3} . \mathrm{It}$ is extremely corrosive \\
Lime & Lime is available in many forms, with quicklime $(\mathrm{CaO})$ and hydrated lime $\left[\mathrm{Ca}(\mathrm{OH})_{2}\right]$ being the most common forms \\
Polymer & Polymers may be available as a prepared stock solution ready for addition to the treatment process or as a dry powder
\end{tabular}


aqueous solutions using $\mathrm{NaOH}, \mathrm{Ca}(\mathrm{OH})_{2}$, or $\mathrm{MgO}$. The results showed that $\mathrm{MgO}$ was very effective in removing heavy metals at pH 9.5-10 (Brbooti et al. 2011). Cr precipitation by combination of $\mathrm{CaO}$ and $\mathrm{MgO}$ to treat the tanning wastewater was evaluated by Geo et al. This mixture precipitates $\mathrm{Cr}$ much quicker than the $\mathrm{NaOH}$ due to the bridging capability of $\mathrm{Ca}^{2+}$ and $\mathrm{Mg}^{2+}$ (Guo et al. 2006). Precipitates that formed are separated by sedimentation occasionally with the help of prior coagulation. The separation process depends to a large extent on the solubility of the precipitates, which could be carbonate, hydroxide, or phosphate salt (Guidance 2014). Factors that affect the process of chemical precipitation are $\mathrm{pH}$, type of precipitating agents, velocity of precipitation, mixing time and speed, sludge volume, and complexing agents (Esmaeili et al. 2009). Complete removal of $\mathrm{Cr}$ from tannery effluent using alkaline precipitation is difficult owing to plenty of organic ligands. Specification of the residual $\mathrm{Cr}$ following alkaline precipitation can show a significant guide for the selection and design of additional treatment processes (Mwinyikione 2010).

\section{Coagulation and flocculation}

Coagulation and flocculation play a prevalent role in various water and wastewater treatments. These techniques are used to form particles large enough to be separated and removed by following sedimentation or alternative clarification processes. From ancient times, people have been using various substances like crushed seeds as coagulants for potable water treatment. The Egyptians were using vessels smeared around with almonds to purify river water as early as 2000 BC. In 1757, alum was used for the treatment of river water in England. Coagulation and flocculation are still important processes of water and wastewater treatment (Wang 2016; Bratby 2006). Coagulation occurs when a coagulant, like alum, is added to the water and wastewater to neutralize the charges on the colloidal particles, thus bringing the particles closer together to permit a floc begin to form. The flocculation technique, following coagulation, permits smaller particles formed during the rapid coagulation step to agglomerate into larger particles to form settle able and/or filterable floc particles. So, the role of a flocculant is to bring together coagulated particles into larger masses and settle them (Pillai 1997). When alum is added to water and wastewater, the following reaction (Eq. 1) occurs (Imran et al. 2012):
In wastewater treatment, coagulation and flocculation process are used to remove or separate colloids, suspended particles, natural organic matters, toxic metals, colour, odour, etc. (Tzoupanos and Zouboulis 2008). Akbal and Camci studied the reduction of $\mathrm{Cr}$ from metal plating wastewater using aluminium sulphate $\left[\mathrm{Al}_{2}\left(\mathrm{SO}_{4}\right)_{3} \cdot 18 \mathrm{H}_{2} \mathrm{O}\right]$ and ferric chloride $\left(\mathrm{FeCl}_{3} \cdot 6 \mathrm{H}_{2} \mathrm{O}\right)$ as coagulants. The study results showed $99.9 \%$ of $\mathrm{Cr}$ removal by chemical coagulation process (Akbal and Camci 2010). Imran et al. used calcium carbonate $\left(\mathrm{CaCO}_{3}\right)$, ammonium aluminium sulphate $\left[\mathrm{NH}_{4} \mathrm{Al}\left(\mathrm{SO}_{4}\right)_{2}\right]$, aluminium sulphate $\left[\mathrm{Al}_{2}\left(\mathrm{SO}_{4}\right)_{2}\right]$, and sodium citrate $\left(\mathrm{Na}_{3} \mathrm{C}_{6} \mathrm{H}_{5} \mathrm{O}_{7}\right)$ coagulants which were immobilized into bead form using sodium alginate to treat tannery effluent. Immobilized ammonium aluminium sulphate was found more effective for the chromium removal from tannery effluent. After treatment, in most cases the $\mathrm{Cr}$ removal value reduced to $<0.5 \mathrm{~g} / \mathrm{l}$ (Imran et al. 2012). Os et al. examined the individual performance of both ferric chloride and organic polymer (a non-ionic polyacrylamide) and performance of ferric chloride-polymer combination for the treatment of beverage industrial wastewater to remove chromium, zinc, and total iron. Combinations of ferric chloride and polymer at different ratios showed better metal removal performances in the range of $69-90 \%$ for zinc, $84-97 \%$ for total chromium, and 69-92\% for total iron, respectively, with minimum sludge (Amuda et al. 2006). Metal salts such as ferric and alum chloride produce sludge which is normally incompact, porous, and difficult to be dewatered due to its high moisture content. Ionic salts, on the other hand, give less sludge volume with bigger and compact flocs. Haydar and Aziz evaluated the performance of cationic polymers as a substitute of metal salts for the treatment of tannery effluent and found 96-97\% of Cr removal (Haydar and Aziz 2009).

\section{Electrochemical treatment (ECT)}

In 1889 , wastewater treatment using electricity was first planned in UK and the application of electrolysis in mineral beneficiation was patented by Elmore in 1904. A largescale drinking water treatment by electrocoagulation was started throughout the USA in 1946 (Chen 2004). Electrochemistry is the branch of chemistry that connects the electrical and chemical effects, and electrochemical treatment (ECT) is a process of passing current through an aqueous

$\mathrm{Al}_{2}\left(\mathrm{SO}_{4}\right)_{3} \cdot 18 \mathrm{H}_{2} \mathrm{O}+3 \mathrm{Ca}\left(\mathrm{HCO}_{3}\right)_{2} \rightarrow 3 \mathrm{CaSO}_{4}+2 \mathrm{Al}(\mathrm{OH})_{3}+6 \mathrm{CO}_{2}+18 \mathrm{H}_{2} \mathrm{O}$

The insoluble aluminium hydroxide, $\mathrm{Al}(\mathrm{OH})_{3}$, is a gelatinous flocculant that settles slowly through the wastewater, sweeping out the suspended material. metal-bearing solution holding a cathode and anode. This is an alternative process for treating wastewater. ECT consists of processes like electro-deposition, electrocoagulation, 
electro-disinfection, electro-oxidation, electro-reduction, electro-osmosis, and electro-flotation (Bard and Faulker 2001; Gunatilake 2015b). This process has created interests among the researchers due to its versatility and eco-friendliness. Here electron is used as a cleaner reagent (BarreraDíaz et al. 2003a).

\section{Electrocoagulation (EC)}

It is the process of destabilization of colloidal particles using electric current through the wastewater. As the current passes through the solution, the anode material undergoes oxidation and cathode gets reduced. Iron and aluminium are usually used as anodes. If iron is used as an anode, then the following reactions (Eqs. 2-4) take place (Barrera-Díaz et al. 2012): Anodic reaction:

$\mathrm{Fe}_{(\mathrm{S})} \rightarrow \mathrm{Fe}_{(\mathrm{aq})}^{2+}+2 \mathrm{e}^{-}$

Cathodic reaction:

$2 \mathrm{H}_{2} \mathrm{O}+2 \mathrm{e}^{-} \rightarrow \mathrm{H}_{2(\mathrm{~g})}+2 \mathrm{OH}^{-}$

Overall:

$\mathrm{Fe}_{(\mathrm{S})}+2 \mathrm{H}_{2} \mathrm{O} \rightarrow \mathrm{Fe}_{(\mathrm{aq})}^{2+}+\mathrm{H}_{2(\mathrm{~g})}+2 \mathrm{OH}^{-}$

Liberated $\mathrm{Fe}^{2+}$ and $\mathrm{OH}^{-}$ions react to form various monomeric and polymeric hydrolysed species. The concentration of the hydrolysed metal species depends on the metal concentration and the solution $\mathrm{pH}$. These types of hydrolysed metal species are responsible for the coagulation of pollutants from solution (Singh et al. 2013). Chemical coagulation is a quite effective process of heavy metals removal from wastewater but generates secondary pollution when coagulants like aluminium or iron salts added to wastewaters for removing colloidal particles as gelatinous hydroxides. Electrocoagulation does not require any chemical species as coagulating agents and is being used successfully in many industrial wastewater treatment (Dermentzis et al. 2018).

\section{Electro-flotation (EF)}

It is a simple process where bubbles are formed electrically to float pollutants on the surface of the wastewater. In the traditional floating process, bubbles are generated from dissolved air under pressure for removing pollutants. EF replaces the bubbles generated from dissolved air by water electrolysis. Hydrogen and oxygen bubbles are generated at the cathode and anode respectively (Mickova 2015). These bubbles collide the suspended particles in the wastewater and float them to the surface of the water which then skimmed off. The basic mechanism lies in the electrolysis of water (Priya 2012).

\section{Electro-oxidation (EO)}

It is a type of advanced oxidation processes (AOP) for wastewater treatment. When electric current is applied through electrodes in the wastewater, strong oxidizing species like . $\mathrm{OH}$ are formed, which interact with the pollutants and degrade them (Wikipedia 2019). For organic wastewater treatment, EO is accomplished in two ways. First, by direct anodic oxidation, in which organics are adsorbed at the electrode and oxidized at the surface of the electrode and second, by indirect oxidation in which some oxidizing agents are produced electrochemically which are responsible for oxidation of organics existing in the wastewater (Kushwaha et al. 2010).

The traditional chromium removal process from wastewater is the reduction process followed by precipitation which produces large amounts of residual sludge. This generated sludge is difficult to manage and transport. That's why new technologies are needed to address and solve the problems. Numerous scientific papers have been published regarding heavy metals removal from wastewater using different electrochemical treatments which are cost-effective, versatile, and eco-friendly. Diaz et al. investigated the chemical and electrochemical processes on the removal of $\mathrm{Cr}$ from aqueous solution. Results revealed that the electrochemical process generated less sludge compared to the chemical process (Barrera-Díaz et al. 2003b). Benhadji et al. studied on simultaneous reduction of organic and inorganic pollutants from tannery effluent by electrocoagulation. Experiments revealed that more than $90 \%$ of $\mathrm{BOD}_{5}, \mathrm{COD}, \mathrm{Cr}$, iron, turbidity, and nitrate were removed (Benhadji et al. 2011). Hunsom et al. designed an anionic membrane reactor consisting of the stainless steel and titanium coated with ruthenium oxide as electrodes to remove $\mathrm{Cu}^{+2}, \mathrm{Cr}^{+6}$, and $\mathrm{Ni}^{+2}$ from plating industrial effluent. More than $99 \%$ metals were reduced in the reactor (Hunsom et al. 2005). Kongsricharoem and Polprasert used electrochemical precipitation process to remove $\mathrm{Cr}^{+6}$ from electroplating wastewater having initial concentration 215-3860 mg/l. After treatment, the remaining concentrations of $\mathrm{Cr}^{+6}$ in the wastewater were less than $0.2 \mathrm{mg} / \mathrm{l}$ (Kongsricharoern and Polprasert 1995). Rana et al. reported $98.5 \%$ electrochemical removal of $\mathrm{Cr}$ from industrial effluent using carbon aerogel electrodes with acidic condition (Rana et al. 2004). Narayanan and Ganesan investigated on $\mathrm{Cr}^{+6}$ removal from synthetic wastewater by batch mode electrocoagulation technique coupled with adsorption using granular activated carbon (GAC). Results showed that maximum chromium removal was archived at $\mathrm{pH}$ near 8.0 (Vivek Narayanan and Ganesan 2009). Murugananthan worked on elctro-flotation technique to remove chromium along with other pollutants such as COD, suspended solids and sulphides from tannery effluent. $\mathrm{Cr}^{+6}$ reduced to $\mathrm{Cr}^{+3}$ by electrochemical precipitation. The chromite $\left(\mathrm{FeCr}_{2} \mathrm{O}_{4}\right)$ 
thus produced was instantaneously floated and removed by electrically produced $\mathrm{H}_{2}$ bubbles. The maximum percentage of $\mathrm{Cr}^{+6}(99.5 \%)$ removal was achieved in the basic range of pH (Murugananthan et al. 2004).

\section{lon exchange}

Ion exchange is a reversible chemical reaction through which ions in solution are exchanged for similar ions attached to a solid matrix. It is very effective for reducing heavy metals from wastewater as it is a cost-effective and convenient process in operations. The solid matrix particles commonly used are synthetic organic ion exchange resins. Naturally occurring inorganic zeolites are also used. Due to its tailoring characteristics to specific applications, synthetic resins are widely used. The exchange resins can take up positively or negatively charged ions from an electrolyte solution and discharge other ions with the same charges in an equivalent amount into the solution (Gunatilake 2015a; Singh and Gupta 2016). During removal, interaction between ion exchange and metals can be expressed as follows (Eq. 5) (Bai and Bartkiewicz 2009):

$n R^{-}-\mathrm{H}^{+}+M^{n+} \leftrightarrow n R^{-}-M_{n+}+n \mathrm{H}^{+}$

where $R^{-}$and $M^{n+}$ represent the anionic group attached to the ion exchange resin and the metal cation, respectively, while " $n$ " is the coefficient of the reaction component which depends on the oxidation state of metal ions.

The ion exchange method is an alternative technique for removal and the recovery of valuable heavy metals from industrial wastewater. Numerous studies were carried out for $\mathrm{Cr}$ removal from wastewaters using ion exchange resins. Cavaco et al. removed $\mathrm{Cr}(\mathrm{III})$ from the electroplating industry using two resins-chelating exchange resin and weak cationic resin. The experimental results revealed that both the resins were effective for the removal of chromium (III) (Cavaco et al. 2007). The removal of $\mathrm{Cr}$ with ion exchange process is recommended by the United States Environmental
Protection Agency (U.S. EPA) and applied successfully by various water utilities of US to produce drinking water (Pakzadeh and Batista 2011). A novel process, namely, Ion Exchange REcovery of CHROMmium(IERECHROM), was developed by Petruzzelli et al. They used macroporous carboxylic resin which removed $\mathrm{Cr}$ from tannery effluent together with other trace metals such as aluminium and iron. Experiments showed that more than $99 \%$ of $\mathrm{Cr}$ was reduced (Petruzzelli et al. 1995). In another study, Cr containing aqueous solution was treated with cation exchange resin and more than 95\% Cr uptake was achieved (Rengaraj et al. 2001).

\section{Membrane filtration}

The word membrane originated from the Latin word membrane which means a skin. It selectively passes the materials. Membrane is used to separate single-celled organisms like bacteria to atom. Abbe Nolet first discovered the ability of the membrane to separate water from solutes in 1748 and coined the word "osmosis" to describe the permeation of water through a diaphragm. The first manmade membranes were made by Fick in 1855 which were made from nitrocellulose (Nath 2008; Tamime 2013). Membrane can be defined as a discontinuous phase between two adjacent phases that permits the exchange of matter, energy, and information between the phases with selective or non-selective properties (Drioli and Giorno 2016). Reverse osmosis (RO), nanofiltration (NF), ultrafiltration (UF), microfiltration (MF), and electrodialysis (ED) are the main membrane separation processes used for wastewater treatment. Here membrane acts like a filter that permits water molecules to pass through while retaining suspended solid and other substances. This process can be pressure-driven or dependent on electrical potential gradient, concentration gradient or other driving forces (Tansel 2008). Some characteristics of membrane separation processes are given in Table 3 (Hankins and Singh 2016):

Table 3 Classification and characteristics of membrane processes used in water treatment

\begin{tabular}{lllll}
\hline Process & Nominal pore size & Driving force & Membrane type & $\begin{array}{c}\text { Average per- } \\
\text { meability }(\mathrm{l} / \\
\left.\mathrm{m}^{2} \mathrm{~h} \text { bar }\right)\end{array}$ \\
\hline Microfiltration & $0.05-10 \mu \mathrm{m}$ & $1-3 \mathrm{bar}$ & Porous, symmetric or asymmetric & 500 \\
Ultrafiltration & $0.001-0.05 \mu \mathrm{m}$ & $2-5 \mathrm{bar}$ & Microporous, asymmetric & 150 \\
Nanofiltration & $<2.0 \mathrm{~nm}$ & $5-15 \mathrm{bar}$ & Tight porous, asymmetric, thin-film composite & $10-20$ \\
Reverse osmosis & $\sim 0.5 \mathrm{~nm}$ & $15-75 \mathrm{bar}$ & Semiporous, asymmetric, thin-film composite & $5-10$ \\
Electrodialysis & $\mathrm{MW}<200 \mathrm{Da}$ & Electrical potential, & Swollen gel, charged, symmetric & - \\
& & $1-2 \mathrm{~V} / \mathrm{cell}$ pair & & - \\
Electrodeionization & $\mathrm{MW}<200 \mathrm{Da}$ & Electrical potential & Swollen gel, charged, symmetric & \\
Membrane degasification & $500-1000$ & Vacuum & Vacuum & \\
\hline
\end{tabular}


Membrane-based wastewater treatment forms a promising avenue for the researchers for providing an effective and sustainable solution of water crisis. It replaces the traditional treatment processes like physical separation techniques, chemical treatment, biological treatment, etc., by the use of selective permeable barriers (Research*eu 2010). Mohammad and Sahu investigated Cr recovery from tannery effluent by RO fitted with UF unit. They found a positive impact on Cr recovery (Mohammed and Sahu 2019). Tripathi and Dwivedi studied on Cr recovery from tannery wastewater using RO. The Cr recovery achieved was $98.66 \%$ by RO treatment at $\mathrm{pH}$ range of 5.6-7, temperature about $25^{\circ} \mathrm{C}$, and pressure of 150 psi (Tripathi and Dwivedi 2012). Integrated membrane process, UF followed by NF, can produce a retentate that can be reused in the chrome tanning. Leather produced by this recovered solution has the same thermal stability as of the leather from the conventional one (Cassano et al. 2007). Membranes modified by plasma treatment have greater flux and $\mathrm{Cr}$ recovery values than that of unmodified membranes (Mickova 2015; Sardohan et al. 2010). Chaudry et al. showed support liquid membrane (SLM) technique for the removal of chromium from tannery effluent treated earlier with mixture of $\mathrm{H}_{2} \mathrm{O}_{2}$ and $\mathrm{NaOH}$ (Chaudry et al. 1998). Faujasite zeolite-based RO membrane rejects more than 95\% $\mathrm{Cr}$, and as hydrophilic, it maintains a high flux (Covarrubias et al. 2008). A combined adsorption-permeation UF membrane process can also remove $\mathrm{Cr}$ from aqueous solution (Pagana et al. 2011). Emulsion liquid membrane (ELM) was observed as a very effective process of removing $\mathrm{Cr}(\mathrm{VI})$ ions successfully from various aqueous solutions (Saravanan and Begum 2006). Sequencing batch membrane reactor(SBMR) is another membrane technique for treating tannery wastewater containing $\mathrm{Cr}$. Yamamoto and Win studied SBMR for Cr removal and found 95.4-97.7\% removal (Yamamoto and Win 1991). Details of reduction of hexavalent chromium, $\mathrm{Cr}(\mathrm{VI})$, from synthetic wastewater by various membranes are listed in Table 4 (Owlad et al. 2009).

\section{Electrodialysis (ED)}

Electrodialysis is an electrochemical process of membrane technology that removes ionic contaminants from an aqueous solution. It was first commercially introduced in 1950 to demineralize brackish water. ED has advanced rapidly due to the advent of upgraded ion exchange membrane properties, improved materials of construction, and advances in technology. In this process, ions are separated through an ion exchange membrane with the help of applied electrical potential between the anode and cathode (Bernardes et al. 2014; Valero et al. 2011). Electrodialysis reversal (EDR), an improvement of ED, was first developed in 1974 by Ionic Int. In EDR process, fouled membranes are self-cleaned by reversing the direction of the constant current. Here the current is altered to dissolve the scale deposited on the membrane which ensures prolonged ED operation (Tanaka 2007). A schematic diagram of electrodialysis is shown in Fig. 5.

In the migration step, cations pass through the cation exchange membranes whereas anions are retained by the anion exchange membrane and vice versa. As a result, similar ions are concentrated in alternate compartments and simultaneously other compartments become depleted. The concentrated solution of ion is called concentrate, and the depleted solution is referred to as product or dilute.

Electrodialysis could be an alternative solution to the conventional tannery effluent treatment (primary and secondary) due to its advantage of enabling the reuse of water and the chemicals present in the effluent which reduce the demand of processing water. In 1970, Mellon and colleagues first introduced ED in the leather industry to remove electrolytes from salted or pickled hides (Bernardes et al. 2014). Rao et al. used ED for Cr uptake from tannery wastewater, and the result showed an improvement in Cr uptake after electrodialysis. Besides $\mathrm{Cr}$, they also removed salts of residual tanning baths (Rao et al. 1989). Hybrid electrocoagulation-electrodialysis process (EC-ED) can remove $100 \% \mathrm{Cr}$ from tannery wastewater. Electrocoagulation (EC) acts as a pre-treatment process which ensures clog-free membrane during ED (Deghles and Kurt 2016). Another study utilized liquid membrane in electrodialysis process for removal
Table 4 Removal of hexavalent chromium by various membranes

\begin{tabular}{lllll}
\hline Membranes & $\begin{array}{l}\text { Initial Cr(VI) con- } \\
\text { centration (mg/l) }\end{array}$ & Removal system & Wastewater & $\begin{array}{l}\text { Rejection } \\
\text { rates (\%) }\end{array}$ \\
\hline Carbon membrane & 1000 & Batch & Synthetic & 96 \\
Nitrated carbon membrane & 1000 & Batch & Synthetic & 84 \\
Aminated carbon membrane & 1000 & Batch & Synthetic & 88 \\
Polymer-enhanced ultra filtration & 10 & Continuous & Synthetic & 30 \\
Composite polyamide membranes & 1000 & Continuous & Synthetic & 99 \\
Composite polyamide membranes & 1000 & Continuous & Synthetic & 94 \\
Polyacrylonitrile fibre & 0.2 & Continuous & Synthetic & 90 \\
\hline
\end{tabular}

年

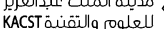




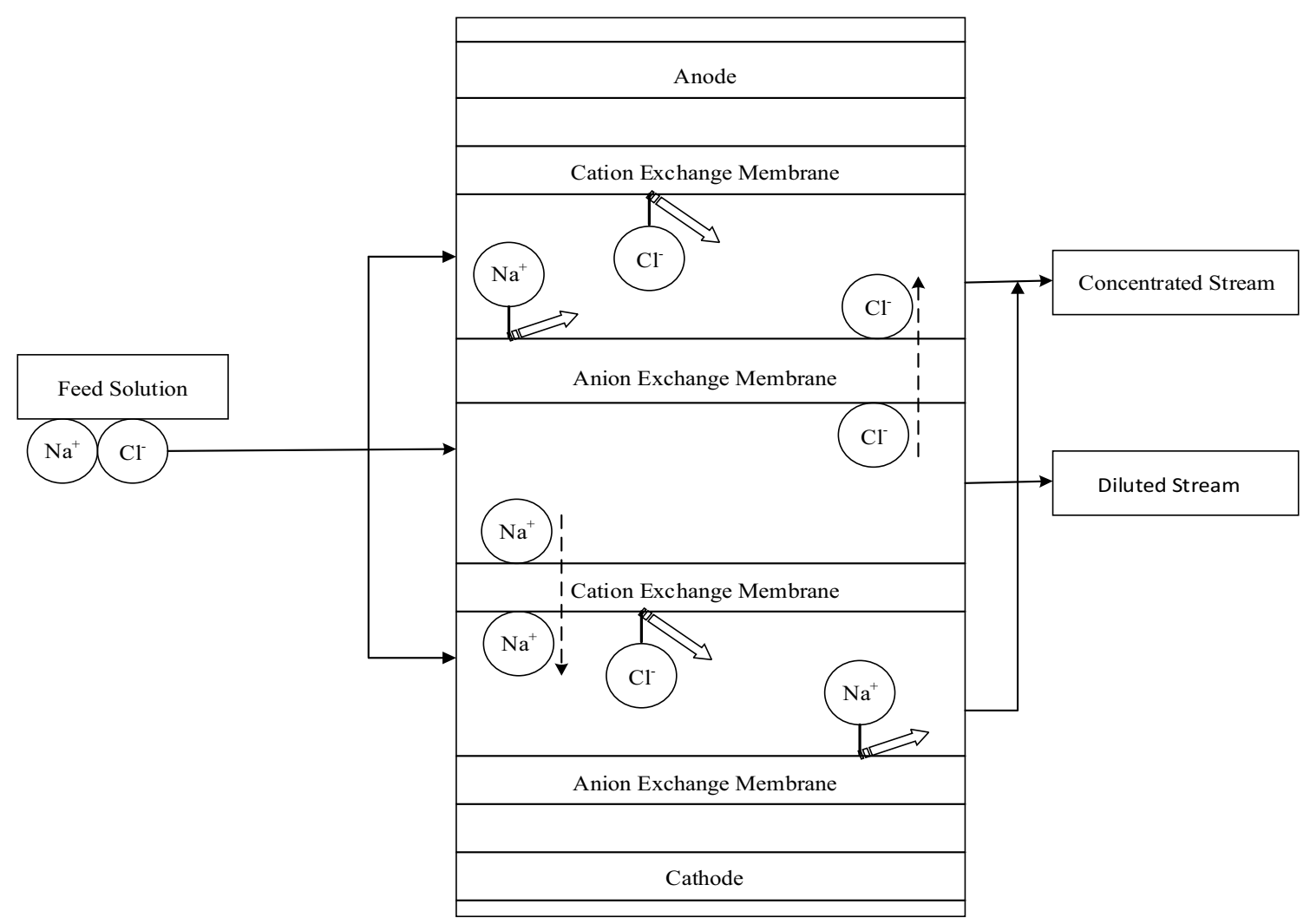

Fig. 5 Process of electrodialysis (Bernardes et al. 2014)

of $\mathrm{Cr}(\mathrm{VI})$ from aqueous solution and obtained about $90 \%$ removal (Sadyrbaeva 2016). Sivakumar et al. compared the results of $\mathrm{Cr}(\mathrm{VI})$ removal by electrodialysis process with a combined process of electrodialysis and adsorption from tannery wastewater where sugarcane bagasse powder was used as an adsorbent. Better result was found, and about $82.5 \% \mathrm{Cr}(\mathrm{VI})$ was removed, with the combined process than the electrodialysis alone (Sivakumar et al. 2014).

\section{Bioremediation}

Bioremediation consists of two parts: "bios" means life and "remediate" means to solve the problems. So bioremediation means to solve the environmental problems by biological organisms. It is a branch of biotechnology which deals with the use of living organisms such as microbes and bacteria to remove contaminants, pollutants, and toxins from soil and water into less toxic forms. Microorganisms, mainly bacteria, can destroy hazardous pollutants or transform them into less harmful forms. These organisms use those contaminants as their sources of food and energy for their growth and reproduction. Contaminants provide a carbon source for new cells production and electrons for energy to the organisms. Effective bioremediation needs a combination of the right nutrients, temperature, and food; if not, it may take much longer for the clean-up of contaminants. Though microorganisms have been utilized for the treatment and transformation of waste products for at least a century, bioremediation is considered as a new ecologically sound technology for the decontamination of polluted environment. Bioremediation can either be done in situ, at the site of the contamination itself, or ex situ. Pollutants are removed from the original site (Goltapeh et al. 2013; Chen 2018; Rittmann et al. 1993). Breakdown of contaminants by organisms is shown in Fig. 6.

The bioremediation process to treat hazardous waste has gained considerable interest as it is effective in reducing the concentration of the heavy metal ions to very low levels, ecologically sound and economical relative to other technologies, and it has been used successfully in many countries (Jahan et al. 2015). Islam worked on Bacillus megaterium and Pseudomonas aeruginosa microorganisms for the uptaking of $\mathrm{Cr}$ from the coal mine effluent and found more than $90 \% \mathrm{Cr}$ uptake for both microorganisms (Islam 2016). Among various methods of $\mathrm{Cr}$ removal, bioremediation could be considered as one of the sustainable solution for controlling $\mathrm{Cr}$ pollution. Bacteria such as Pseudomonas spp., Bacillus spp. Acinetobacter spp., Burkholderia spp., fungi like Paecilomyces spp., Aspergillus spp., Penicillium spp., Rhizopus spp., Yeast Candida spp., Saccharomyces spp., and algae are used as microorganisms 


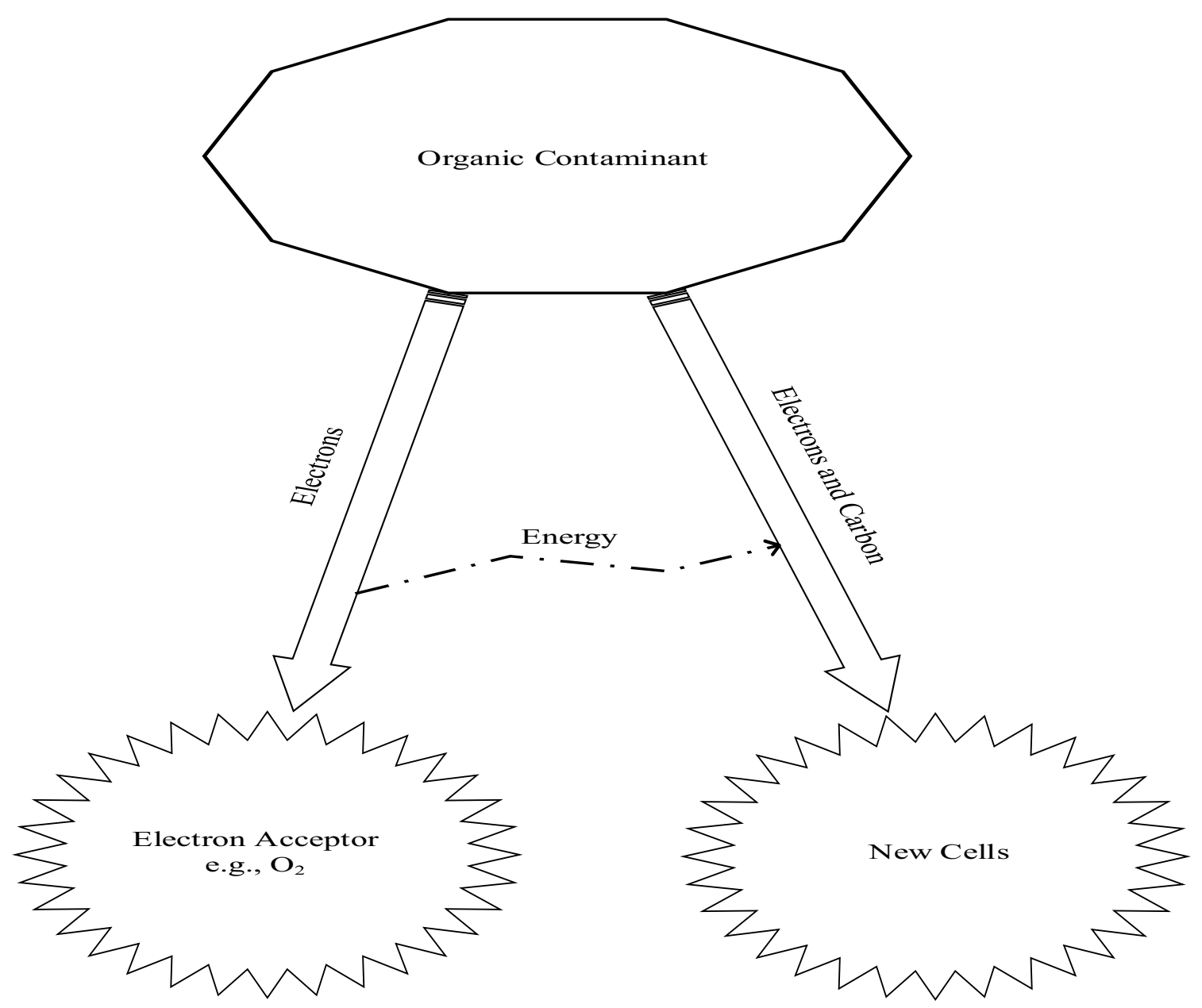

Fig. 6 Breakdown of contaminants by organisms (Rittmann et al. 1993)

in different studies for Cr removal (Bhattacharya et al. 2019). When hexavalent chromium is bio-remediated at a neutral $\mathrm{pH}$ range generates small quantity of chemical sludge. During bioremediation, $\mathrm{Cr}(\mathrm{VI})$ is highly soluble in bacteria and is transported via the sulphate pathway across the cell membrane, finally reduced in the cytoplasm to $\mathrm{Cr}$ (III). This $\mathrm{Cr}$ (III) interacts with protein and nucleic acids and cannot pass through the cell membrane (Saranraj and Sujitha 2013). Mythili and Karthikeyan evaluated the biosorption of Chromium by Bacillus spp. and Staphylococcus spp. microorganism from tannery wastewater whose initial concentration was $100 \mathrm{mg} / \mathrm{l}$. Under the optimum conditions, the highest chromium uptake was $94.5 \mathrm{mg} / \mathrm{Lat} \mathrm{pH} 7$ and $92.9 \mathrm{mg} / \mathrm{l}$ at temperature $37^{\circ} \mathrm{C}$ for Bacillusspp and for Staphylococcus spp., it was $72.3 \mathrm{mg} / \mathrm{l}$ at $\mathrm{pH} 8.0$ and $72.6 \mathrm{mg} / \mathrm{l}$ at temperature $37^{\circ} \mathrm{C}$ (Mythili and Karthikeyan 2011). $\mathrm{Cr}(\mathrm{VI})$ removal by trickling filter is a new biological approach of $\mathrm{Cr}$ reduction. Dermouet al. studied three different modes of trickling filter operations (batch, continuous, and SBR with recirculation) using indigenous bacteria (Acinetobacter sp.) as inoculum for the filter. The results concluded high removal rates of $\mathrm{Cr}(\mathrm{VI})$ from industrial wastewater (Dermou et al. 2005).

Algae such as Spirullina sp., Chlorella sp., Scenedesmus sp., and Scenedesmus sp. are known for their ability to remove metals due to the presence of polysaccharides in their cells which make easy adsorption of heavy metals. Fungi have the ability to trap and absorb the material through their hyphae and aid in the metabolism (Christopher et al. 2016). Srivastava and Takur investigated the biosorption of $\mathrm{Cr}$ from tannery effluent using Aspergillus sp. fungi, and $85 \%$ of chromium was removed at $\mathrm{pH}$ 6 in a bioreactor system (Srivastava and Thakur 2006). Park et al. proposed a new mechanism of $\mathrm{Cr}(\mathrm{VI})$ removal by the dead fungal biomass of Aspergillus niger from the synthetic wastewater. The mechanism of $\mathrm{Cr}(\mathrm{VI})$ was the redox reaction between $\mathrm{Cr}(\mathrm{VI})$ and the dead fungal biomass (Park et al. 2005). 


\section{Phytoremediation}

Another class of bioremediation process is phytoremediation which utilizes the plants and its physical characteristics for remediation of contaminants. The term "phytoremediation" is copied from the Greek word Phyto (means plant) and Latin word Remedium (to remove an evil). This process consists of several mechanisms such as phytostabilization, phytoextraction, phytovolatilization, phytodegradation, and phytostimulation, etc. It is a cost-effective solution which uses plants and associated soil microbes to reduce contaminants in the environment (Das and Osborne 2018; Greipsson 2011). Phytoremediation is a bioremediation process that uses various types of plants to remove, transfer, stabilize, and/or destroy contaminants in the soil and groundwater (Willey 2007; TechTree 2019).

Phytostabilization Contaminants are stabilized in the roots or within the rhizosphere, and therefore, they retained in the soil.

Phytoextraction Plants absorb contaminants and store in above-ground shoots and the harvestable biomass.

Phytodegradation It involves the degradation of organic contaminants using the enzymes released from roots or through metabolic activities within plant tissues.

Phytovolatilization In this process, contaminants are uptaken by the plant roots and converted to gaseous state and finally released into the atmosphere.

Phytostimulation Plant roots stimulate soil microbial communities to break down the contaminants.

Bioadsorbents like Jasminum (Santiago and Santhamani 2010), Eichhorniacraassipes (Chakrabarty et al. 2017), Cyprus alterifolius, Typha domingensis, Parawaldeckia, Borassusaethiopum (Tadesse and Seyoum 2015), Typha spp. (Dotro et al. 2009), Polygonum coccineum, Brachiaramutica, Cyprus papyrus (Kassaye et al. 2017), Hyptissuaveolens (Sivakumar et al. 2016), Chrysopogonzizanioides, Cyperusrotundus, (Bekele 2018) and Trichoderma (Vankar and Bajpai 2008) have potential to remove $\mathrm{Cr}$ from tannery soil and wastewater.

\section{Removal of Cr from tannery wastewater of Bangladesh by waste tea leaves: a case study}

Preceding sections of the chapter present an overview of total chromium $(\mathrm{Cr})$ removal techniques for wastewaters generated from different industrial activities involving heavy metals like chromium. These sections also provide overall technical and chemical information of methods such as adsorption, electrocoagulation, chemical precipitation, membrane separation, ion exchange, and electrodialysis that have been adopted for the removal of chromium from tannery wastewater. In addition, these divisions present observations and results of different studies carried on chromium removal as well as suggest about the potentiality of some low-cost agriculture wastes such as rice husk, waste tea leaves, neem leaves, coconut coir, banana peel, and sawdust to remove $\mathrm{Cr}$ from tannery wastewater. Though leather sector of Bangladesh is contributing to the country's economy remarkably, tanning activities of Tanneries are conversely posing great threats to the total environment and human health; therefore, extensive research has been going on the low-cost removal technique of Chromium $(\mathrm{Cr})$.

The following part discusses in depth $\mathrm{Cr}$ removal from tannery wastewater of Bangladesh which was studied by Nur-E-Alam et al. (2018) using low-cost spent tea leaves as a case study for providing information in the context of Bangladesh within the limited frame of works. They dealt with the removal of $\mathrm{Cr}$ using spent tea leaves as an adsorbent from tannery wastewater of the Hazaribagh Tanning Area of Dhaka City-the capital of Bangladesh, where most of country's tanneries were located and carried out from November 2016 to January 2017.

\section{Background and state of the problem}

Tanneries of Bangladesh are considered as the most polluting industries. In Bangladesh, leather industries are well established and leather sector is ranked fourth in terms of earning foreign exchange. The first tannery of Bangladesh was established at Narayanganj by R.P. Shaha in 1940. Later on, it was shifted to Hazaribagh area in Dhaka city. In 1965, there were only 30 tanneries in the then East Pakistan now Bangladesh (Mamun et al. 2016). Though both chrome and vegetable tanning are extensively used all over the world, most of the tanneries of Bangladesh produce chrome-tanned leather and thus discharge a huge quantity of chromium with the untreated effluents to the nearby water bodies which degrade the environment seriously and increase the human health risks (Nur-E-Alam et al. 2018). These tannery wastewaters also contain some other heavy metals such as $\mathrm{Fe}, \mathrm{Na}, \mathrm{Zn}, \mathrm{Cr}, \mathrm{Pb}$, and $\mathrm{Ca}$ (Thakur and Parmar 2013). Realizing the hazardous impact of tannery wastes on human and environment, the Government of Bangladesh has taken a project under Bangladesh Small and Cottage Industries Corporation (BSCIC) to shift tanneries from Hazaribagh Tannery Complex to Savar Tannery Estate. At present, 115 tanneries out of 155 industries have started their operations at Savar Tannery Estate. All wastewaters coming out from these tanneries are now treated in the common effluent treatment plant (CEPT).

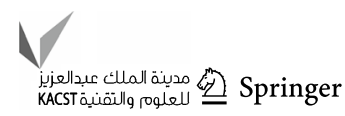




\section{Source of waste tea leaves}

Bangladesh is one of the largest tea manufacturer in the world. Presently, the country has 172 commercial tea estates, including many of the world's largest working plantations. The industry accounts for $3 \%$ of global tea production and employs more than 4 million people (Nasir and Shamsuddoha 2011). Being formerly a major tea exporter, Bangladesh is now a net importer of tea. The tea consumption per year from 2010 to 2014 was 57.63, $58.50,61.19,64.00$ and $67.17 \mathrm{M} \mathrm{kg}$, respectively (Board 2018 ), and is growing day by day. The growth of tea production is now $1 \%$ per year, whereas the consumption of tea is increasing at 3.5\% per year (Khan et al. 2012). The annual per capita consumption of tea in Bangladesh was $0.390 \mathrm{~kg}$ in 2013 (Helgilibrary 2013). Once the tea has been brewed, the spent tea leaves become a waste that must be disposed of which creates disposal problems. A conventional disposal scenery of tea waste of Bangladesh is shown in Fig. 7. After water, tea is the most widely consumed beverage in the world (Nandal et al. 2014). These tea wastes can be used for wastewater treatment as adsorbent.

\section{Adsorption as a $\mathrm{Cr}$ removal technique}

Adsorption is the process of adhering molecules from fluid phase to the surface of a solid. It has advantages over other methods of $\mathrm{Cr}$ removal from wastewaters. It is simple in design, produces zero sludge, and requires less initial costs as well as small investment for land (Liu et al. 2009). The adsorption abilities of a number of lowcost adsorbents such as cheap zeolites, clay, coal fly ash, sewage sludge, agriculture waste, and biomass have been studied by many researchers for the removal of heavy metals from wastewater.

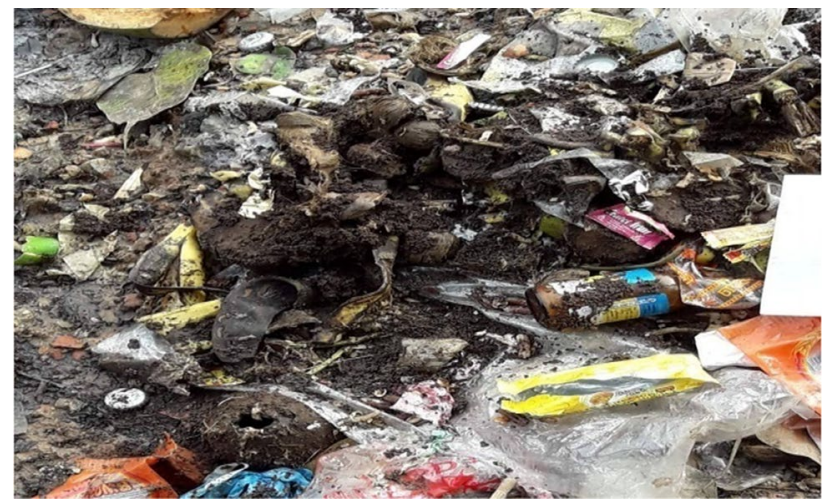

Fig. 7 Traditional disposal of tea waste (Authors)

\section{Waste tea leaves as adsorbent}

Tea is one of the most popular beverages, and about 3.5 million tons of tea is consumed annually in the world. Tea has become an essential drink in our life. Since tea leaves waste is cheap and abundantly available, its proper utilization as adsorbent could bring a potential approach towards wastewater treatment (Boonamnuayvitaya et al. 2004; Wan et al. 2014). Very few studies have investigated waste tea leaves as an adsorbent for the treatment of tannery effluent. Recently, a great number of studies have been devoted to the treatment of wastewater by using adsorption techniques with various low-cost materials. As a result, waste tea leaves is also gaining grounds as an adsorbent due to its potential for the treatment of wastewater. Insoluble cell walls of tea leaves are substantially made up of cellulose and hemicelluloses, lignin, condensed tannins and structural proteins. For removal of the organic contaminants from industrial wastewater, adsorption has become one of the best effective and inexpensive methods; thus, this process has aroused considerable interest during recent years (Wang et al. 2006). Kulkarni and Goswami found 90-95\% removal of organic matters by using bagasse flyash (Kulkarni and Goswami 2013). According to Mukundan and Ratnoji, activated carbon from rice husk can remove $92.37 \%$ COD of sewage (Mukundan and Ratnoji 2015). Low-cost adsorbents of different origins like industrial waste materials, corn stalks, peat, rice husk, saw dust, bagasse fly ash, peels of various fruits, and jute-processing wastes can also be used for removal of organic matter from wastewater. Avocado peel carbons can also remove about $98.20 \%$ COD and $99.18 \%$ BOD from coffee processing wastewaters (Devi et al. 2008).

The cooked tea waste, which is discarded as waste material from residence, teashops, and restaurant proved to be an effective adsorbent for the removal of $\mathrm{Cr}(\mathrm{VI})$ from industrial wastewater (Bhavsar and Patel 2014). Nowadays, tea waste is receiving much attention of researchers also for its good biosorption ability in removing heavy metals like Iron (II), $\mathrm{Cr}(\mathrm{VI}), \mathrm{Pb}$, and Ni. Researchers are now focused on the development of a suitable technology either to prevent heavy metal pollution or to reduce it to a low level. Prevention of entrance of heavy metal into the nearby water bodies can possibly be done only by reducing their direct discharge into the water stream. The most widely used conventional methods for removing heavy metals have many disadvantages such as requirement of high capital and operational cost, unsuitability for small-scale industries and inadequate efficiency. Tea waste is a good option as it is a low-cost adsorbent for the removal of heavy metals from wastewaters. Many studies show almost cent per cent efficiency of tea waste for removing heavy metals (Nandal et al. 2014). According to Amarasinghe and Williams, more than $90 \%$ of $\mathrm{Pb}$ and $\mathrm{Cu}$ were removed using tea waste from wastewater 
(Amarasinghe and Williams 2007). Waste mud of copper mine can also be used as adsorbent for the removal of $\mathrm{Pb}$ (II) ions from aqueous solutions (Ozdes et al. 2009). Neem leaves can remove chromium (VI) from wastewater as well (Gopalakrishnan et al. 2013). As tea leaves consist of some functional groups related with cellulose, hemicelluloses, lignin, condensed tannins, and structural proteins, these functional groups are greatly responsible for good metal uptake (Nandal et al. 2014; Wang et al. 2006; Aikpokpodion et al. 2010) which were confirmed by FTIR analysis (Fig. 8).

\section{Materials and methods}

\section{Sample collection}

Tannery effluents were collected from a tannery outlet as well as from a drain near the Institute of Leather Engineering and Technology (ILET) under the University of Dhaka located at Hazaribagh Area of Dhaka City Corporation in November 2016. Pre-washed plastic bottles were used for collecting 3(three) samples-one samples from a drain near ILET main gate (Sample 1) and second sample from a tannery outlet (Sample 2), and the other from a drain situated behind ILET (Sample 3). Tea waste is a cheap material that is easily available in Bangladesh from various sources such as tea stalls, restaurants, public and private offices, tea factories, community centres and so on. Adsorbent sample (waste tea leaves) was collected from some local tea stalls near Leather Research Institute (LRI) under Bangladesh Council of Scientific and Industrial Research (BCSIR) located at Savar of Dhaka Division of Bangladesh. Therefore, its utilization in water and wastewater treatment particularly in tannery effluent would be convenient.

\section{Preparing spent tea leaves as adsorbent}

The teashops, restaurants, hotels, and offices which were usually discarded as waste in the surrounding sides. Soluble and coloured components of the tea wastes, collected from tea stalls near LRI under BCSIR, were removed by washing with boiling water. Washing of waste tea leaves carried out until the wash water became virtually colourless. The tea leaves were then washed with distilled water and oven dried for $12 \mathrm{~h}$ at $105^{\circ} \mathrm{C}$. Washed tea leaves, thus fully prepared as adsorbent, are shown in Fig. 9 b.

\section{Scanning electron microscope (SEM) analysis}

The SEM image of spent tea leaves is shown in Fig. 10. The surface of waste tea leaves was found smooth, uneven and with uniformly wide microporous structures. Usually, the rough surface and widely distributed pores can offer greater surface area and more binding sites for adsorbing metals (Wan et al. 2014).

\section{Chromium adsorption}

The experiment was performed as a batch process in a series of beakers equipped with stirrers to stir the tannery effluent with adsorbent. The batch process was selected for its simplicity (Bhavsar and Patel 2014). At the end of predetermined time, the suspension was filtered and the remaining concentration of the metal ions in the aqueous phase was measured by Atomic Absorption Spectrophotometer (AAS). A known volume of sample effluent $(250 \mathrm{ml})$ was conducted with varying adsorbent dose (03-20 g/l), contact time (30-80 min), and $\mathrm{pH}(4-10)$ at room temperature. The

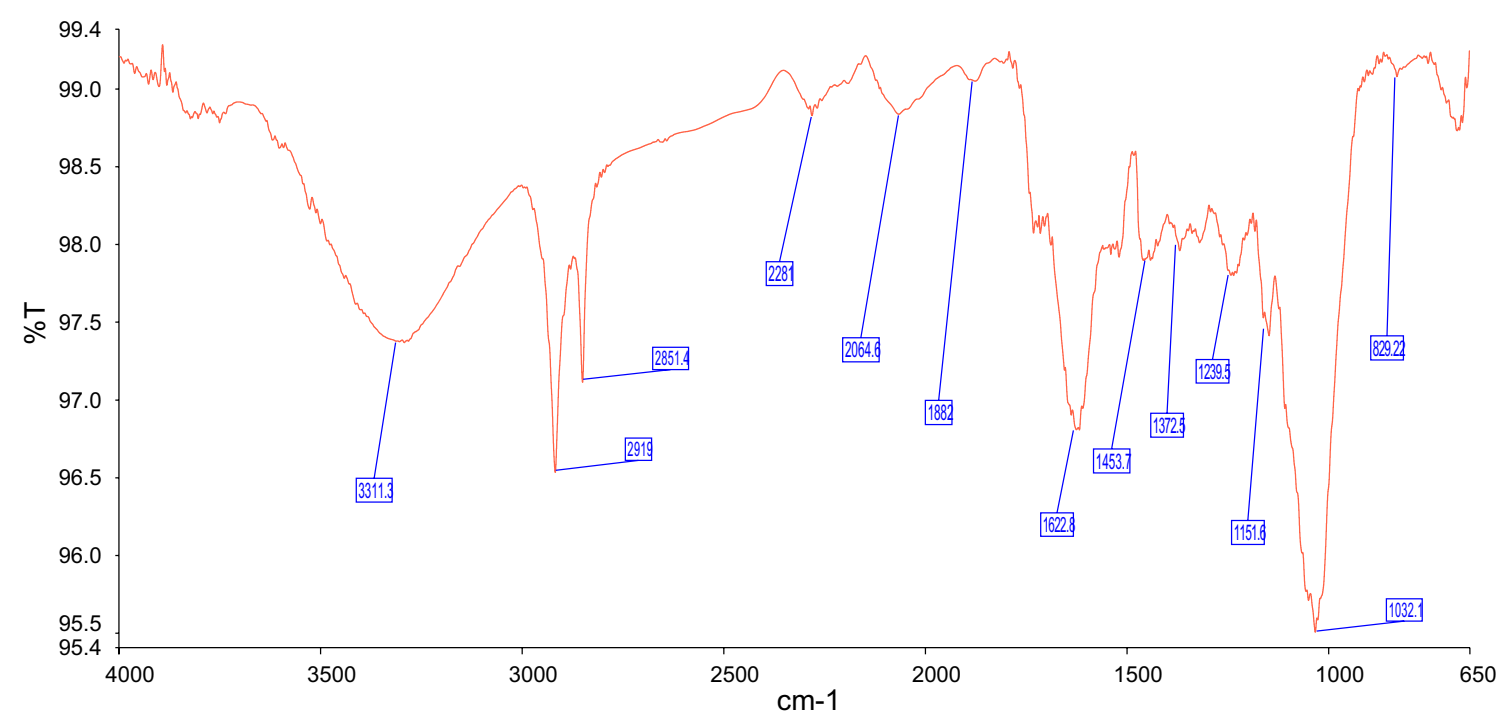

Fig. 8 FTIR spectra of waste tea leaves (Nur-E-Alam et al. 2018) 


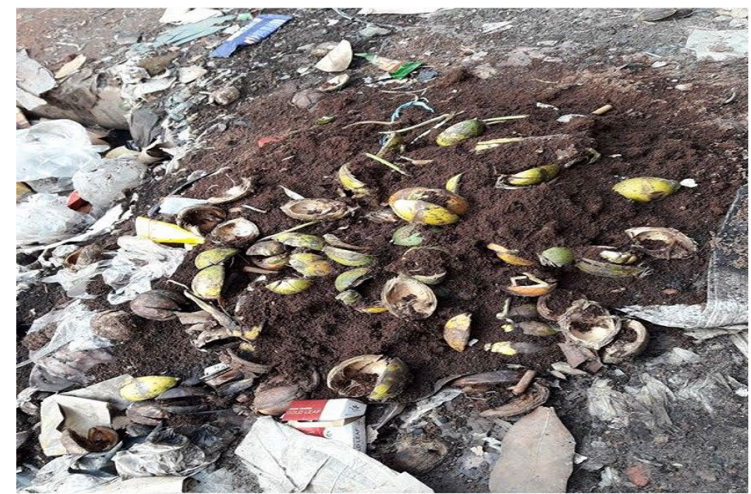

(a)

Fig. 9 a Disposed tea waste at roadside, $\mathbf{b}$ tea waste prepared as adsorbent

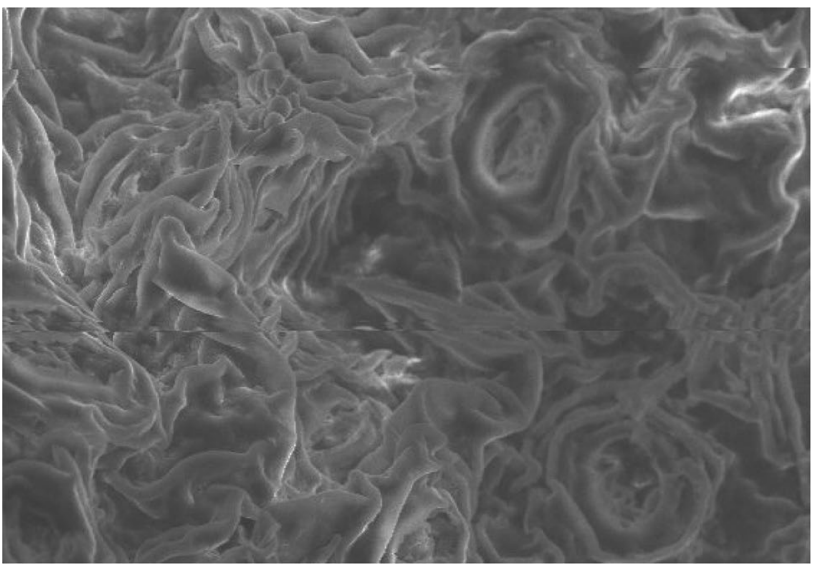

Fig. 10 SEM analysis of waste tea leaves

Table 5 Characteristics of tannery wastewater sample (Nur-E-Alam et al. 2018)

\begin{tabular}{llll}
\hline Parameter & Sample S1 & Sample S2 & Sample S3 \\
\hline pH & 6.5 & 8.2 & 6.2 \\
BOD $(\mathrm{mg} / \mathrm{l})$ & 1700 & 12,600 & 2100 \\
$\mathrm{COD}(\mathrm{mg} / \mathrm{l})$ & 2490 & 21,060 & 3200 \\
$\mathrm{Cr}(\mathrm{mg} / \mathrm{l})$ & 10.35 & 616.770 & 15.40 \\
\hline
\end{tabular}

adsorptive solution consists of washed tea leaves as well as $\mathrm{NaOH}$ and $\mathrm{HCl}$ solution. Characteristics ( $\mathrm{pH}, \mathrm{BOD}, \mathrm{COD}$, and $\mathrm{Cr}$ concentrations) of tannery wastewaters of various locations are shown in Table 5.

\section{Effect of adsorbent dose}

Adsorbent-adsorbate solutions of varying adsorbents were prepared for studying the effect of adsorbent dose for 60 min shown in Fig. 11. For all the samples, the

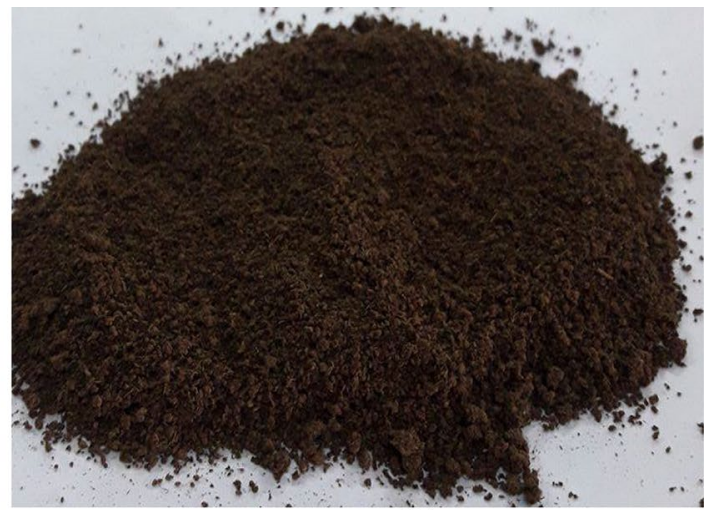

(b)

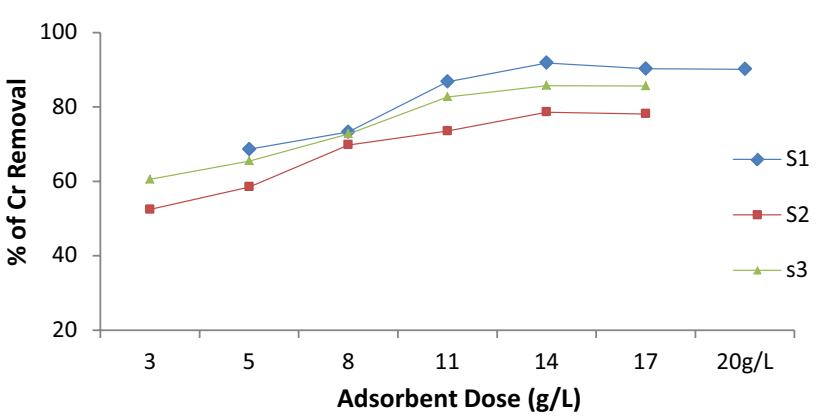

Fig. 11 Effect of adsorbent dose on Cr removal (Nur-E-Alam et al. 2018)

percentage of $\mathrm{Cr}$ removal was increased with the adsorbent dose up to $14 \mathrm{~g} / 1$ which were about $91.79,78.60$ and 85.71 for Samples S1, S2, and S3, respectively. It is evident that the percentage removals of metals increase rapidly with an increase in the adsorbents dose owing to the greater availability of the exchangeable sites or surface area (Thakur and Parmar 2013

\section{Effect of contact time}

Here adsorbent dose of $14 \mathrm{~g} / \mathrm{l}$ (optimum dose) was taken fixed for different time periods (30-180 min) and shaking the solution. The best percentages of $\mathrm{Cr}$ removals were attained at times of 60, 150, and 60 min for Sample S1, Sample S2, and Sample S3 which were about 91.79, 85.4, and 88.64\%, respectively, as shown in Fig. 12. It is assumed from the above figure that the contact time needed to reach equilibrium is dependent on the initial concentrations of the solution contents. The percentage of removal increases with time until equilibrium is attained for the samples of the same concentration. 


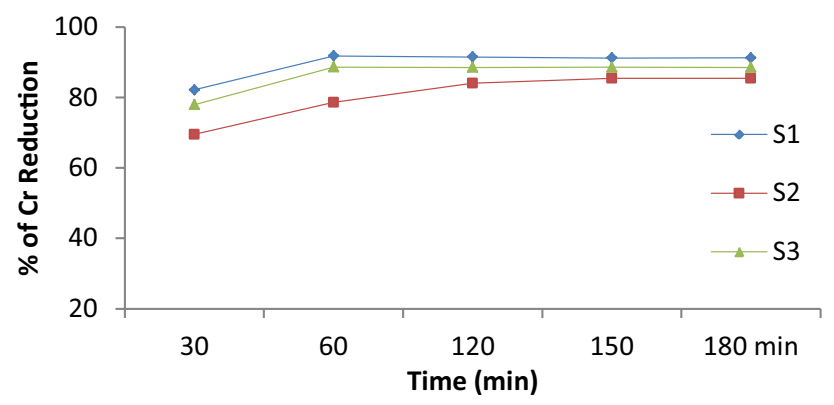

Fig. 12 Effect of contact time on Cr removal (Nur-E-Alam et al. 2018)

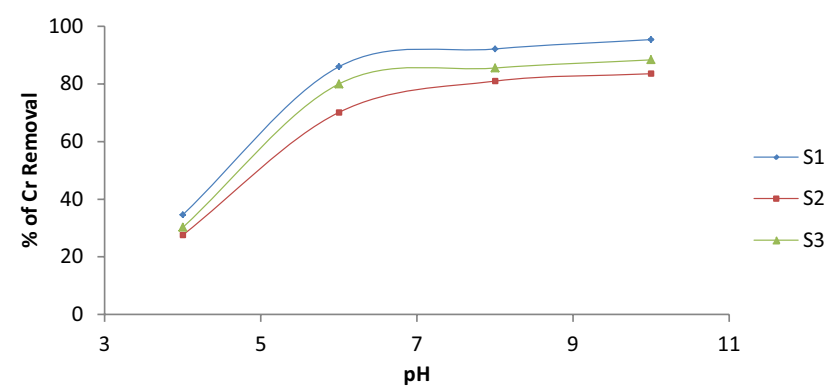

Fig. 13 Effect of $\mathrm{pH}$ on Cr removal (Nur-E-Alam et al. 2018)

\section{Effect of $\mathrm{pH}$}

The adsorption process was conducted at a constant adsorbent dose of $14 \mathrm{~g} / \mathrm{l}$ and for different agitation periods of 60 , 150, and $60 \mathrm{~min}$ for Sample S1, Sample S2, and Sample S3, respectively, shown in Fig. 13. The highest percentages of $\mathrm{Cr}$ reductions were obtained at $\mathrm{pH} 10$ for all the samples which were about $95.42,83.57$, and $88.38 \%$, respectively. As $\mathrm{pH}$ increases, the percentage of $\mathrm{Cr}$ removal increases because of the de-protonation of binding sites which makes different functional groups available for metal binding and vice versa (Dhabab 2011).

\section{Adsorption isotherms}

Adsorption isotherm is an equilibrium plot of the solidphase (qe) versus liquid-phase concentration (Ce) at fixed temperature. Freundlich and Langmuir's isotherms are the simplest known relationships which describing the adsorption equation.

Freundlich adsorption isotherm From the Freundlich isotherm model as shown in Fig. 14, constants obtained are

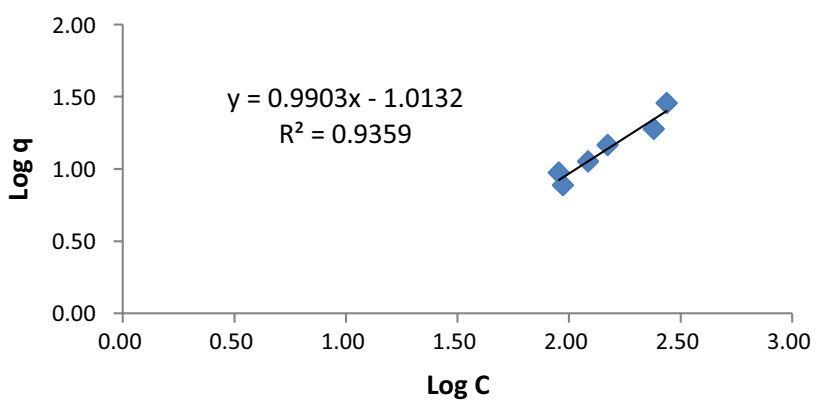

Fig. 14 Freundlich isotherm of spent tea waste

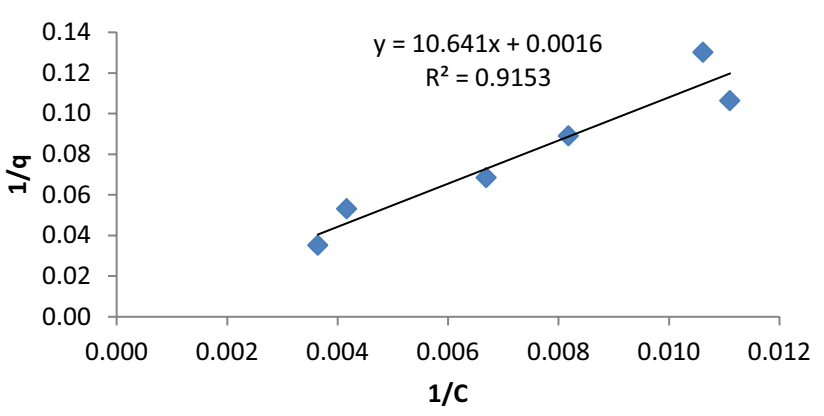

Fig. 15 Langmuir adsorption isotherm of spent tea waste

adsorption capacity, $K_{\mathrm{f}}$ is -1.01 and adsorption intensity, $1 / n$ is 0.99 . The regression coefficient is 0.935 .

Langmuir adsorption isotherm The Langmuir equation was used to describe the data derived from the adsorption of $\mathrm{Cr}$ from the wastewater shown in Fig. 15. The constants obtained are: Langmuir constant $K_{\mathrm{L}}$ is 0.002 and maximum adsorption capacity is 10.64 . The regression coefficient is 0.915 .

Therefore, both Langmuir and Freundlich adsorption isotherms can be used for justification of $\mathrm{Cr}$ adsorption using spent tea leaves.

\section{SEM analysis}

Scanning electron microscope (SEM) images of spent tea leaves before and after treatment of tannery wastewaters are shown in Fig. 16. SEM image is used to observe the surface morphologies. Pores, gaps, slits, or channels can be seen as well as useful information regarding pore structures can be obtained by SEM image (Gundogdu et al. 2013). The surface of the waste tea leaves was found smooth having a uniform microporous structure before treatment of tannery wastewater samples (Fig. 16a). After treatment, the surface of the tea waste adsorbent becomes saturated due to the adsorption as shown in Fig. 16b.

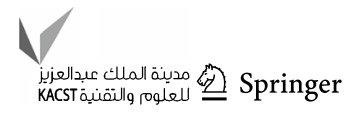




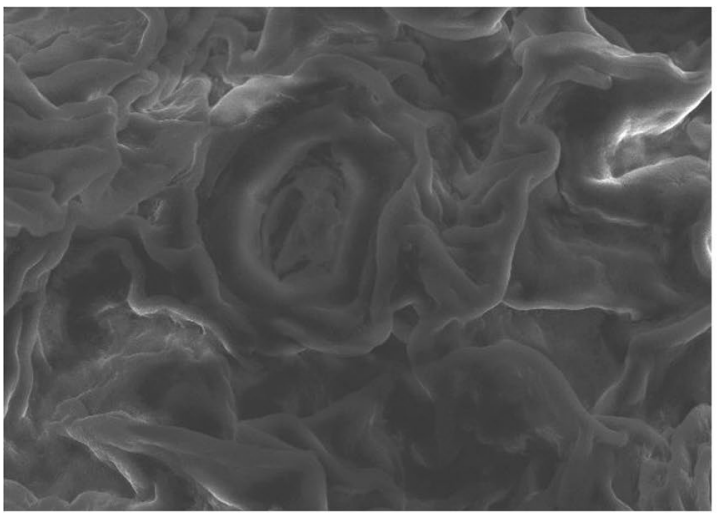

(a)

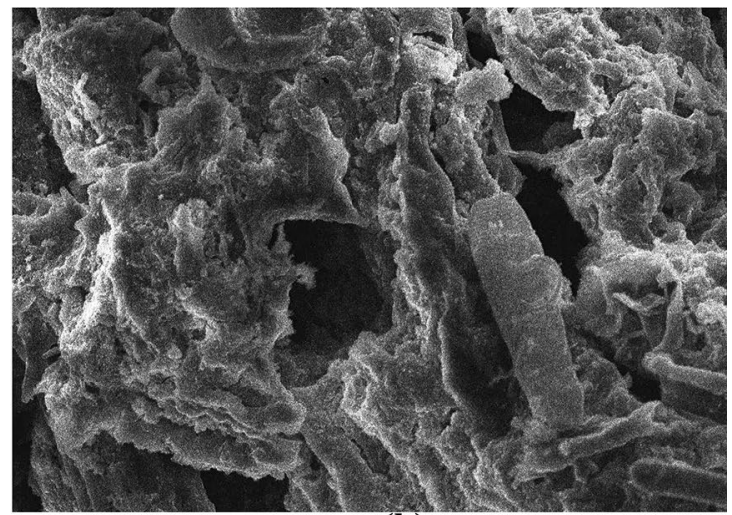

(b)

Fig. 16 a SEM images of waste tea leaves before treatment, $\mathbf{b}$ SEM images of waste tea leaves after treatment

\section{Conclusion}

Chromium $(\mathrm{Cr})$ as a heavy metal is very detrimental to human health, animals, and the environments when its concentration level goes beyond the standard permissible level. Industrial activities particularly the leather tanning processes contribute a substantial amount of $\mathrm{Cr}$ to the tannery wastewater. If this $\mathrm{Cr}$-rich effluent is not treated properly, then it finally mixes with the neighbouring water bodies and pollutes the water. But this pollution does not remain in water only but spreads to other abiotic components of environment such as soil, groundwater, and even to biotic components like plants and animals. As a result, the ecological balance of the environment will be affected seriously. There are a number of methods of treating chromium from tannery wastewater. Some of these methods result in more than $90 \%$ chromium removal from the tannery wastewaters. Typically, these sorts of technologies are expensive, sophisticated, and energy-intensive and need skilled personnel as well to operate. However, process like adsorption is very economical, simple, effective, and versatile. Numerous lowcost agriculture wastes such waste tea leaves, sugar bagasse, coconut coir, banana peel, rice husk, sawdust, eggshell, etc., have potential as adsorbents and possess required adsorption properties for removal of $\mathrm{Cr}$ from wastewaters particularly from tannery effluent.

Acknowledgements This research was supported by CASR Research Fund, BUET.

Author contributions MNA and MASM carried out a major part of the literature review and drafted the manuscript. FA carried out literature review for selected sections. MNA conceived the study. MMR supervised the research project and helped to finalize the manuscript. All authors read and approved the final manuscript.

Funding The case study was supported by CASR Research Fund, BUET.

\section{Compliance with ethical standards}

Conflict of interest The authors declare that they have no conflict of interest.

Ethical approval Research and manuscript are original and unpublished. All authors read and approved the final manuscript.

Open Access This article is licensed under a Creative Commons Attribution 4.0 International License, which permits use, sharing, adaptation, distribution and reproduction in any medium or format, as long as you give appropriate credit to the original author(s) and the source, provide a link to the Creative Commons licence, and indicate if changes were made. The images or other third party material in this article are included in the article's Creative Commons licence, unless indicated otherwise in a credit line to the material. If material is not included in the article's Creative Commons licence and your intended use is not permitted by statutory regulation or exceeds the permitted use, you will need to obtain permission directly from the copyright holder. To view a copy of this licence, visit http://creativecommons.org/licenses/by/4.0/.

\section{References}

Abbas N, Deba F, Iqbal K, Shafique T, Ahmed HS (2010) Treatability study for tannery wastewater by precipitation process. Pak J Sci Ind Res

Abdulla HM, Kamal EM, Mohamed AH, El-bassuony AD (2010) Chromium removal from tannery wastewater using chemical and biological techniques aiming zero discharge of pollution. In: Proceeding fifth science environmental conference, vol VI, pp 171-183

Aikpokpodion PE, Ipinmoroti RR, Omotoso SM (2010) Biosorption of nickel (II) from aqueous solution using waste tea (Camella cinencis) materials. Am J Toxicol Sci 2(2):72-82

Akan J, Abdulrahman F, Ayodele J, Ogugbuaja V (2009) Impact of tannery and textile effluent on the chemical characteristics of Challawa. Aust J Basic Appl Sci 3(3):1933-1947

Akbal F, Camci S (2010) Comparison of electrocoagulation and chemical coagulation for heavy metal removal. Chem Eng Technol 33(10):1655-1664 
Amarasinghe BMWPK, Williams RA (2007) Tea waste as a low cost adsorbent for the removal of $\mathrm{Cu}$ and $\mathrm{Pb}$ from wastewater. Chem Eng J 132(1-3):299-309

Amir A, Rahim RNRA, Abdul-Talib S (2017) Removal of chromium hexavalent using agriculture waste. Int J Environ Sci Dev $8(4): 260-263$

Amuda O, Amoo I, Ipinmoroti K, Ajayi O (2006) Coagulation/flocculation process in the removal of trace metals present in industrial wastewater. J Appl Sci Environ Manag 10(3):1-4

ATSDR (2014) Effect hydrogen sulfide $\left(\mathrm{H}_{2} \mathrm{~S}\right)$. Available: https://www. atsdr.cdc.gov $/ \mathrm{mmg} / \mathrm{mmg}$. asp? $\mathrm{id}=385 \& \mathrm{tid}=67$

Babu R, Bhadrinarayana N, Begum KMMS, Anantharaman N (2007) Treatment of tannery wastewater by electrocoagulation. J Univ Chem Technol Metall 42(2):201-206

Bai Y, Bartkiewicz B (2009) Removal of cadmium from wastewater using ion exchange resin Amberjet $1200 \mathrm{H}$ columns. Pol J Environ Stud 18(6):1191-1195

Bansal M, Garg U, Singh D, Garg VK (2009) Removal of Cr(VI) from aqueous solutions using pre-consumer processing agricultural waste: a case study of rice husk. J Hazard Mater 162(1):312-320

Bard AJ, Faulker LR (2001) Electrochemical methods fundamentals and applications, 2nd edn. Wiley, New York

Barrera-Díaz C, Ureña-Nuñez F, Campos E, Palomar-Pardavé M, Romero-Romo M (2003a) A combined electrochemical-irradiation treatment of highly colored and polluted industrial wastewater. Radiat Phys Chem 67(5):657-663

Barrera-Díaz C, Palomar-Pardavé M, Romero-Romo M, Martínez S (2003b) Chemical and electrochemical considerations on the removal process of hexavalent chromium from aqueous media. J Appl Electrochem 33(1):61-71

Barrera-Díaz CE, Lugo-Lugo V, Bilyeu B (2012) A review of chemical, electrochemical and biological methods for aqueous Cr(VI) reduction. J Hazard Mater 223-224:1-12

Bekele M (2018) Phytoremediation of tannery waste water using horizontal sub surface flow constructed wetland. College of Biological and Chemical Engineering, Madison

Belay AA (2010) Impacts of chromium from tannery effluent and evaluation of alternative treatment options. J Environ Prot (Irvine Calif) 1(1):53-58

Benhadji A, Taleb Ahmed M, Maachi R (2011) Electrocoagulation and effect of cathode materials on the removal of pollutants from tannery wastewater of Rouïba. Desalination 277(1-3):128-134

Bernardes AM, Rodrigues MAS, Ferreir JZ (2014) Electrodialysis and water reuse: novel approaches. Springer, Berlin

Bhattacharya A, Gupta A, Kaur A, Malik D (2019) Alleviation of hexavalent chromium by using microorganisms: insight into the strategies and complications. Water Sci Technol 79(3):411-424

Bhavsar K, Patel P (2014) Efficiency evaluation of tea waste for adsorption of hexavalent chromium from industrial effluent. Int J Sci Res ISSN (Online Impact Factor) 3(7):2319-7064

Birhanie M, Leta S, Khan MM (2017) Removal of hazardous pollutants from tannery wastewater by naval filter medium (Pumice) through adsorption and filtration method. IOSR J Environ Sci Toxicol Food Technol 11(9):38-45

Board BT (2018) History of tea industry. Available: http://teaboard. portal.gov.bd/site/page/4f91c2f2-7cb4-44eb-b690-7e4dab3d5d 86/History-of-Tea-Industry-

Boonamnuayvitaya V, Chaiya C, Tanthapanichakoon W, Jarudilokkul S (2004) Removal of heavy metals by adsorbent prepared from pyrolyzed coffee residues and clay. Sep Purif Technol 35(1):11-22

Bratby J (2006) Coagulation and flocculation in water and wastewater treatment, 2nd edn. IWA Publishing, London
Brbooti MM, Abid BA, Al-shuwaiki NM (2011) Removal of heavy metals using chemicals precipitation. Eng Technol J 29:595-612

Cassano A, Della Pietra L, Drioli E (2007) Integrated membrane process for the recovery of chromium salts from tannery effluents. Ind Eng Chem Res 46(21):6825-6830. https://doi.org/10.1021/ ie070144n

Cavaco SA, Fernandes S, Quina MM, Ferreira LM (2007) Removal of chromium from electroplating industry effluents by ion exchange resins. J Hazard Mater 144(3):634-638

Chakrabarty T, Afrin R, Mia Y, Hossen Z (2017) Phytoremediation of chromium and some chemical parameters from tannery effluent by using water. Res Agric Livest Fish 4(3):151-156

Chamon AS, Gerzabek MH, Mondol MN, Ullah SM, Rahman M, Blum WEH (2005) Influence of soil amendments on heavy metal accumulation in crops on polluted soils of Bangladesh. Commun Soil Sci Plant Anal 36(7-8):907-924

Chaudry MA, Ahmad S, Malik MT (1998) Supported liquid membrane technique applicability for removal of chromium from tannery wastes. Waste Manag 17(4):211-218

Chemicool (2012) Chromium element facts. Available: https://www. chemicool.com/elements/chromium.html

Chen G (2004) Electrochemical technologies in wastewater treatment. Sep Purif Technol 38(1):11-41

Chen J (2018) Bioremediation. Investopedia. Available: https://www. investopedia.com/terms/b/bioremediation.asp

Christopher JG, Kumar G, Tesema AF, Thi NBD, Kobayashi T, Xu K (2016) Bioremediation for tanning industry: a future perspective for zero emission. In: Management of hazardous wastes. INTECH, pp 91-102

Covarrubias $\mathrm{C}$ et al (2008) Removal of trivalent chromium contaminant from aqueous media using FAU-type zeolite membranes. J Membr Sci 312(1-2):163-173

Das A, Osborne JW (2018) Bioremediation of heavy metals. In: Nanotechnology, food security and water treatment. Springer, Berlin

Das AC, Sultana R, Sultana MS (2015) Impact of tannery on the worker's reproductive health in the area of Hazaribagh in Dhaka, Bangladesh. Int J Res 2(6):159-181

Deghles A, Kurt U (2016) Treatment of tannery wastewater by a hybrid electrocoagulation/electrodialysis process. Chem Eng Process Process Intensif 104:43-50

Dermentzis K, Christoforidis A, Valsamidou E, Lazaridou A, Kokkinos N (2018) Removal of hexavalent chromium from electroplating wastewater by electrocoagulation with iron electrodes. Glob NEST J 13(4):412-418

Dermou E, Velissariou A, Xenos D, Vayenas DV (2005) Biological chromium(VI) reduction using a trickling filter. J Hazard Mater 126(1-3):78-85

Devi R, Singh V, Kumar A (2008) COD and BOD reduction from coffee processing wastewater using Avacado peel carbon. Bioresour Technol 99(6): 1853-1860

Dhabab JM (2011) Removal of some heavy metal ions from their aqueous solutions by duckweed. J Toxicol Environ Heal Sci 3(June): $164-170$

Do DD (1998) Introduction. In: Do DD (ed) Adsorption analysis: equilibria and kinetics. Imperial College Press, London, pp 1-2

Dokken K et al (1999) Characterization of chromium(VI) bioreduction and chromium(III) binding to Alfalfa biomass. In: Proceedings of 1999 conference on hazardous waste research, vol VI, pp 101-113

Dotro G, Palazolo P, Larsen D (2009) Chromium fate in constructed wetlands treating tannery wastewaters. Water Environ Res 81(6):617-625

Drioli E, Giorno L (2016) Encyclopedia of membranes. Springer, Berlin

Dutta S (1999) An introduction to the principles of leather manufacture. Indian Leather Technologist Association, Kolkata

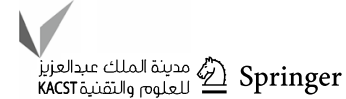


El Nemr A (2007) Pomegranate husk as an adsorbent in the removal of toxic chromium from wastewater. Chem Ecol 23(5):409-425

Emongor V, Nkegbe E, Kealotswe B, Koorapetse I, Sankwasa S, Keikanetswe S (2005) Pollution indicators in gaborone industrial effluent. J Appl Sci 5(1):147-150

Esmaeili A, Mesdaghinia A, Vazirineja R (2009) Chromium (III) removal and recovery from tannery wastewater by precipitation process. Am J Appl Sci 2(10):1471-1473

Fahim NF, Barsoum BN, Eid AE, Khalil MS (2006) Removal of chromium(III) from tannery wastewater using activated carbon from sugar industrial waste. J Hazard Mater 136(2):303-309

Fathima NN, Aravindhan R, Rao JR, Nair BU (2005) Solid waste removes toxic liquid waste: adsorption of chromium(VI) by iron complexed protein waste. Environ Sci Technol 39(8):2804-2810

Fu F, Wang Q (2011) Removal of heavy metal ions from wastewaters: a review. J Environ Manag 92(3):407-418

Gao P, Chen X, Shen F, Chen G (2005) Removal of chromium(VI) from wastewater by combined electrocoagulation-electroflotation without a filter. Sep Purif Technol 43(2):117-123

Goltapeh EM, Danesh YR, Varma A (2013) Fungi as bioremediators. Springer, Berlin

Gopalakrishnan S, Kannadasan T, Velmurugan S, Muthu S, Vinoth Kumar P (2013) Biosorption of chromium (VI) from industrial effluent using neem leaf adsorbent. Res J Chem Sci 3(4):48-53

Grassi M, Kaykioglu G, Belgiorno V, Lofrano G (2012) Removal of emerging contaminants from water and wastewater by adsorption process. In: Lofrano G (ed) Emerging compounds removal from wastewater. Springer, Berlin, p 19

Greipsson S (2011) Phytoremediation. Nat Educ Knowl 3(10):7

Gunatilake SK (2015a) Methods of removing heavy metals from industrial wastewater. J Multidiscip Eng Sci Stud 1(1):12-18

Gunatilake SK (2015b) Methods of removing heavy metals from industrial wastewater. J Multidiscip Eng Sci Stud 1(1):13-18

Gundogdu A, Duran C, Senturk HB, Soylak M, Imamoglu M, Onal Y (2013) Physicochemical characteristics of a novel activated carbon produced from tea industry waste, vol 104. Elsevier, Amsterdam

Guo ZR, Zhang G, Fang J, Dou X (2006) Enhanced chromium recovery from tanning wastewater. J Clean Prod 14(1):75-79

Hafez AI, El-Manharawy MS, Khedr MA (2002) RO membrane removal of unreacted chromium from spent tanning effluent. A pilot-scale study, part 2. Desalination 144(1-3):237-242

Hankins NP, Singh R (2016) Emerging membrane technology for sustainable water treatment. Elsevier, Amsterdam

Hashem MA, Jor A (2015) Gaseous air pollutants and its environmental effect-emitted from the tanning industry at Hazaribagh, Bangladesh. Am J Eng Res 4(5):138-144

Haydar S, Aziz JA (2009) Coagulation-flocculation studies of tannery wastewater using cationic polymers as a replacement of metal salts. Water Sci Technol 59(2):381-390

Helgilibrary (2013) Tea consumption per capita in Bangladesh. Available: http://www.helgilibrary.com/indicators/tea-consu mption-per-capita/bangladesh/

Hintermeyer B, Lacour N, Padilla AP, Tavani E (2008) Separation of the chromium(III) present in a tanning wastewater by means of precipitation, reverse osmosis and adsorption. Lat Am Appl Res 38(1):63-71

Human Rights Watch (2012) Toxic tanneries: The Health Repercussions of Bangladesh's Hazaribagh Leather

Hunsom M, Pruksathorn K, Damronglerd S, Vergnes H, Duverneuil $\mathrm{P}$ (2005) Electrochemical treatment of heavy metals $\left(\mathrm{Cu}^{2+}\right.$, $\left.\mathrm{Cr}^{6+}, \mathrm{Ni}^{2+}\right)$ from industrial effluent and modeling of copper reduction. Water Res 39(4):610-616

Imran Q, Hanif MA, Riaz MS, Noureen S, Ansari TM, Bhatti HN (2012) Coagulation/flocculation of tannery wastewater using immobilized chemical coagulants. J Appl Res Technol 10(2):79-86

Islam HS (2016) Bioremediation of chromium. Res J Chem Environ 20(1):34-42

Jahan M, Akhtar N, Khan N, Roy C, Islam R, Nurunnabi M (2015) Characterization of tannery wastewater and its treatment by aquatic macrophytes and algae. Bangladesh J Sci Ind Res 49(4):233-242

Kankaria S, Andukuri A, Hemamailini CG, Krishnaveni M (2011) Impact of tannery effluent on groundwater and agriculture with a remedial measure - a case study. In: International conference on chemical, biological and environment sciences (ICCEBS'2011). IMPACT, Bangkok, pp 383-388

Kassaye G, Gabbiye N, Alemu A (2017) Phytoremediation of chromium from tannery wastewater using local plant species. Water Pract Technol 12(4):894-901

Khan A, Biswas A, Saha A, Motalib M (2012) Soil preparation of Lalmai Hill, Shalban Bihar and Nilachal Hill of Greater Comilla District and its sustability for tea plantation. Tea J Bangladesh 41:17-26

Kocaoba S, Akcin G (2002) Removal and recovery of chromium and chromium speciation with MINTEQA2. Talanta 57(1):23-30

Komori K, Rivas A, Toda K, Ohtake H (1990) A method for removal of toxic chromium using dialysis-sac cultures of a chromatereducing strain of Enterobacter cloacae. Appl Microbiol Biotechnol 33(1):117-119

Kongsricharoern N, Polprasert C (1995) Electrochemical precipitation of chromium $\left(\mathrm{Cr}^{6+}\right)$ from an electroplating wastewater. Water Sci Technol 31(9):109-117

Kowalski Z (1994) Treatment of chromic tannery wastes. J Hazard Mater 37(1):137-141

Kulkarni SJ, Goswami AK (2013) Adsorption studies for organic matter removal from wastewater by using bagasse flyash in batch and column operations. Int J Sci Res 2(11):180-183

Kulkarni P, Kalyani V, Mahajani VV (2007) Removal of hexavalent chromium by membrane-based hybrid processes. Ind Eng Chem Res 46:8176-8182

Kushwaha JP, Srivastava VC, Mall ID (2010) Organics removal from dairy wastewater by electrochemical treatment and residue disposal. Sep Purif Technol 76(2):198-205

Lambert J, Rakib M, Durand G, Avila-Rodríguez M (2006) Treatment of solutions containing trivalent chromium by electrodialysis. Desalination 191(1-3):100-110

Liu Y, Cao Q, Luo L, Chen J (2009) Biosorption of $\mathrm{Cd}^{2+}, \mathrm{Cu}^{2+}, \mathrm{Ni}^{2+}$ and $\mathrm{Zn}^{2+}$ ions from aqueous solutions by pretreated biomass of brown algae. J Hazard Mater 163:931-938

Lovley DR, Coates JD (2003) Bioremediation of metal contamination. Environ Monit Assess 84(1-2):45-60

Malik DS, Jain CK, Yadav AK, Vishwavidyalaya GK, Division EH, Vishwavidyalaya GK (2015) Preparation and characterization of plant based low cost. J Glob Biosci 4(1):1824-1829

Mamun A, Howlader S, Yeahyea HB, Uddin MR (2016) Leather industry of Bangladesh: a new hope for export diversification editorial overview. Emerging Credit Rating Limited, Dhaka

Margarida Alves M, González Beça CG, de Carvalho RG, Castanheira JM, Sol Pereira MC, Vasconcelos LAT (1993) Chromium removal in tannery wastewaters 'polishing' by Pinus sylvestris bark. Water Res 27(8):1333-1338

Mickova I (2015) Advanced electrochemical technologies in wastewater treatment. Part II: electro-flocculation and electro-flotation. Am Sci Res J Eng Technol Sci 14(2):273-294

Minas F, Chandravanshi BS, Leta S (2017) Chemical precipitation method for chromium removal and its recovery from tannery wastewater in Ethiopia. Chem Int 3(4):291-305 
Mohammed K, Sahu O (2019) Recovery of chromium from tannery industry waste water by membrane separation technology: health and engineering aspects. Sci Afr 4:e00096

Mondal NC, Saxena VK, Singh VS (2005) Impact of pollution due to tanneries on groundwater regime. Curr Sci 88(12):1988-1994

Mondol MN, Asia A, Chamon AS, Faiz SMA (2017) Contamination of soil and plant by the Hazaribagh tannery industries. J Asiat Soc Bangladesh Sci 43(December):207-222

Mukundan U, Ratnoji SS (2015) COD removal from sewage by activated carbon from rice husk-an agricultural by product. Int J Innov Res Sci Eng Technol 4(6):5003-5007

Murugananthan M, Raju GB, Prabhakar S (2004) Separation of pollutants from tannery effluents by electro flotation. Sep Purif Technol 40(1):69-75

Mwinyikione M (2010) Ecotoxicological diagnosis in the tanning industry. Springer, Berlin

Mythili K, Karthikeyan B (2011) Bioremediation of Cr(VI) from tannery effluent using Bacillus spp and Staphylococcus spp. Int Multidiscip Res J 1(6):38-41

Nandal M, Hood R, Dhania G (2014) Tea wastes as a sorbent for removal of heavy metals from wastewater. Int J Curr Eng Technol 4(1):1-5

Nasir T, Shamsuddoha M (2011) Tea productions, consumptions and exports: Bangladesh. Int J Educ Res Technol 2(1):68-73

Nath K (2008) Membrane separation processes. Prentice-Hall of India, New Delhi

Nerenberg R, Rittmann BE (2004) Hydrogen-based, hollow-fiber membrane biofilm reactor for reduction of perchlorate and other oxidized contamitants. Water Sci Technol 49(11-12):223-230

Nur-E-Alam M, Abu Sayid Mia M, Ahmad F, Mafizur Rahman M (2018) Adsorption of chromium (Cr) from tannery wastewater using low-cost spent tea leaves adsorbent. Appl Water Sci 8(5): 129

Ouejhani A, Hellal F, Dachraoui M, Lallevé G, Fauvarque JF (2008) Application of Doehlert matrix to the study of electrochemical oxidation of $\mathrm{Cr}(\mathrm{III})$ to $\mathrm{Cr}(\mathrm{VI})$ in order to recover chromium from wastewater tanning baths. J Hazard Mater 157(2-3):423-431

Owlad M, Aroua MK, Daud WAW, Baroutian S (2009) Removal of hexavalent chromium-contaminated water and wastewater: a review. Water Air Soil Pollut 200(1-4):59-77

Ozdes D, Gundogdu A, Kemer B, Duran C, Senturk HB, Soylak M (2009) Removal of $\mathrm{Pb}$ (II) ions from aqueous solution by a waste mud from copper mine industry: equilibrium, kinetic and thermodynamic study. J Hazard Mater 166(2-3):1480-1487

Pagana AE, Sklari SD, Kikkinides ES, Zaspalis VT (2011) Combined adsorption-permeation membrane process for the removal of chromium (III) ions from contaminated water. J Membr Sci 367(1-2):319-324

Pakzadeh B, Batista JR (2011) Chromium removal from ionexchange waste brines with calcium polysulfide. Water Res 45(10):3055-3064

Panda RC, Lajpathi Rai C, Sivakumar V, Baran Mandal A (2012) Odour removal in leather tannery. Adv Chem Eng Sci 2(2):199-203

Panizza M, Cerisola G (2016) Electrochemical oxidation as a final treatment of synthetic tannery wastewater. Environ Sci Technol 38(February):5470-5475

Park D, Yun YS, Jo JH, Park JM (2005) Mechanism of hexavalent chromium removal by dead fungal biomass of Aspergillus niger. Water Res 39(4):533-540

Payel S, Sarker M (2018) Banana rachis charcoal to remove chromium from tannery wastewater. In: 4th international conference on civil engineering for sustainable development, 9-11 February 2018. KUET, Khulna, Bangladesh, vol 1, pp 1-8
PETA (2019) Environmental hazards of leather. Available: https:// www.peta.org/issues/animals-used-for-clothing/leather-indus try/leather-environmental-hazards/

Petruzzelli D, Passino R, Tiravanti G (1995) Ion exchange process for chromium removal and recovery from tannery wastes. Ind Eng Chem Res 34(8):2612-2617

Pillai J (1997) Flocculants and coagulants: the keys to water and waste management in aggregate production

Polti MA, Amoroso MJ, Abate CM (2007) Chromium(VI) resistance and removal by actinomycete strains isolated from sediments. Chemosphere 67(4):660-667

Poopal AC, Laxman RS (2009) Studies on biological reduction of chromate by Streptomyces griseus. J Hazard Mater 169(1-3):539-545

Prado AGS et al (2010) Application of Brazilian sawdust samples for chromium removal from tannery wastewater. J Therm Anal Calo$\operatorname{rim}$ 99(2):681-687

Priya PG (2012) Degradation studies of tannery effluents using electro flotation technique. J Chem Eng Process Technol 2(1):2-5

Ramakrishnaiah CR, Prathima B (2012) Hexavalent chromium removal from industrial watsewater by chemical precipitation method. Int J Eng Res Appl 2(2):599-603

Rana P, Mohan N, Rajagopal C (2004) Electrochemical removal of chromium from wastewater by using carbon aerogel electrodes. Water Res 38(12):2811-2820

Rao JR, Prasad BGS, Narasimhan V, Ramasami T, Shah PR, Khan AA (1989) Electrodialysis in the recovery and reuse of chromium from industrial effluents. J Membr Sci 46(2-3):215-224

Rengaraj S, Yeon KH, Moon SH (2001) Removal of chromium from water and wastewater by ion exchange resins. J Hazard Mater 87(1-3):273-287

Research*eu (2010) Membrane technologies for water applications. European Union

R. Guidance (2014) Chemical precipitation, 1, pp 9-12

Rittmann BE et al (1993) In situ bioremediation: when does it work? National Academy Press, Washington

Rydin S, Black M, Scalet BM, Canova M (2013) Best available techniques (BAT) reference document for the tanning of hides and skins. Eur Comm Database 46:2013

Sadyrbaeva TZ (2016) Removal of chromium(VI) from aqueous solutions using a novel hybrid liquid membrane-electrodialysis process. Chem Eng Process Process Intensif 99(VI):183-191

Sahu SK, Meshram P, Pandey BD, Kumar V, Mankhand TR (2009) Removal of chromium(III) by cation exchange resin, Indion 790 for tannery waste treatment. Hydrometallurgy 99(3-4):170-174

Santiago M, Santhamani S (2010) Remediation of chromium contaminated soils: potential for phyto and bioremediation. In: 19th world congress of soil science, soil solutions for a changing world, pp 211-214

Santosa SJ, Siswanta D, Sudiono S, Utarianingrum R (2008) Chitinhumic acid hybrid as adsorbent for $\mathrm{Cr}$ (III) in effluent of tannery wastewater treatment. Appl Surf Sci 254(23):7846-7850

Saranraj P, Sujitha D (2013) Microbial bioremediation of chromium in tannery effluent: a review. Int J Microbiol Res 4(3):305-320

Saravanan S, Begum K (2006) Removal of hexavalent chromium by emulsion liquid membrane technique. J Univ Chem Technol Metall 41(3):333-342

Sardohan T, Kir E, Gulec A, Cengeloglu Y (2010) Removal of Cr(III) and $\mathrm{Cr}(\mathrm{VI})$ through the plasma modified and unmodified ionexchange membranes. Sep Purif Technol 74(1):14-20

Saxena G, Chandra R, Bharagava RN (2016) Environmental pollution, toxicity profile and treatment approaches for tannery wastewater and its chemical pollutants. In: Whitacre DM (ed) Reviews of environmental contamination and toxicology, vol 240. Springer, Berlin 
Shen TT (1999) Industrial pollution prevention, 2nd edn. Springer, Berlin

Silvateam (2020) Hybrid chrome tanning. Silvateam. Available: https ://www.silvateam.com/en/products-and-services/leather-tanningsolutions/ecotan-tanning-processes/hybrid-chrome-tanning.html

Singh N, Gupta S (2016) Adsorption of heavy metals: a review. Int J Innov Res Sci Eng Technol 5(2):2267-2281

Singh S, Srivastava VC, Mall ID (2013) Multistep optimization and residue disposal study for electrochemical treatment of textile wastewater using aluminum electrode. Int J Chem React Eng 11(1):31-46

Sivakumar D (2015) Hexavalent chromium removal in a tannery industry wastewater using rice husk silica. Glob J Environ Sci Manag $1(1): 27-40$

Sivakumar D, Shankar D, Kandaswamy AN, Ammaiappan M (2014) Role of electro-dialysis and electro-dialysis cum adsorption for chromium (VI) reduction. Pollut Res 33(3):547-552

Sivakumar P, Kanagappan M, Das SSM (2016) Phytoremediation of tannery waste polluted soil using Hyptis suaveolens (Lamiaceae). Int J Pure Appl Biosci 4(1):265-272

Spellman F (2017) The science of environmental pollution, 3rd edn. CRC Press, Boca Raton

Srivastava S, Thakur IS (2006) Isolation and process parameter optimization of Aspergillus sp. for removal of chromium from tannery effluent. Bioresour Technol 97(10):1167-1173

Stoller M, Sacco O, Vilardi G, Ochando Pulido JM, Di Palma L (2017) Chromium recovery by membranes for process reuse in the tannery industry. In: 15th international conference on environmental science and technology, Rhodes

Swathanthra PA, Rao VV (2014) Adsorption of chromium (VI) from aqueous solution using a solid waste (Bagasse). Int J Emerg Trends Eng Dev 5(3):330-336

Tadesse AT, Seyoum LA (2015) Evaluation of selected wetland plants for removal of chromium from tannery wastewater in constructed wetlands, Ethiopia. Afr J Environ Sci Technol 9(5):420-427

Tamime A (2013) Membrane processing: dairy and beverage applications. Blackwell Publishing Ltd, Hoboken

Tanaka Y (2007) Ion exchange membranes: fundamentals and applications, vol 12. Membrane science and technology series. Elsevier, Amsterdam

Tansel B (2008) New technologies for water and wastewater treatment: a survey of recent patents. Recent Pat Chem Eng 1(1):17-26

TechTree (2019) Phytoremediation. Available: http://www.cpeo.org/ techtree/ttdescript/phytrem.htm

Thakur LS, Parmar M (2013) Adsorption of heavy metal from synthetic waste water by tea waste adsorbent. Int J Chem Phys Sci 2(6):6-19

Thorstensen TC (1999) Fundamentals of pollution control for the leather industry. Shoe Trades Publishing Co, 8

Tripathi A, Dwivedi AK (2012) Studies on recovery of chromium from tannery. J Ind Pollut Control 28(1):29-34

Tripathi A, Rawat Ranjan M (2015) Heavy metal removal from wastewater using low cost adsorbents. J Bioremediat Biodegrad $6(6): 315$
Tzoupanos ND, Zouboulis AI (2008) Coagulation-flocculation processes in water/wastewater treatment : the application of new generation of chemical reagents. In: 6th IASME/WSEAS international conference on heat transfer thermal engineering environment, pp 309-317

U. Essays (2018) Environmental impact of Leather Tanning Industry. Available: https://www.ukessays.com/essays/environmentalsciences/environmental-impact-of-leather-tanning-industry-envir onmental-sciences-essay.php?vref $=1$

USEPA (2000) Wastewater technology fact sheet dechlorination. Environmental Protection Agency, Washington, pp 1-7

Valero F, Barcelo A, Arbos R (2011) Electrodialysis technology. Theory and applications. In: Desalination, trends and technologies. pp 1-20

Vankar PS, Bajpai D (2008) Phyto-remediation of chrome-VI of tannery effluent by Trichoderma species. Desalination 222(1-3):255-262

Vivek Narayanan N, Ganesan M (2009) Use of adsorption using granular activated carbon (GAC) for the enhancement of removal of chromium from synthetic wastewater by electrocoagulation. $\mathrm{J}$ Hazard Mater 161(1):575-580

Wan S et al (2014) Sorption of lead (II), cadmium (II), and copper (II) ions from aqueous solutions using tea waste. Ind Eng Chem Res 53(9):3629-3635

Wang S, Soudi M, Li L, Zhu Z (2006) Coal ash conversion into effective adsorbents for removal of heavy metals and dyes from wastewater. J Hazard Mater 133(1-3):243-251

Wang D et al (2016) Chromium speciation in tannery effluent after alkaline precipitation: isolation and characterization. J Hazard Mater 316:169-177

Wikipedia (2019) Electro-oxidation. Available: https://en.wikipedia. org/wiki/Electro-oxidation

Willey N (2007) Phytoremediation methods and review. Humana Press Inc, Totowa

Worch E (2012) Introduction. In: Worch E (ed) Adsorption technology in water treatment: fundamentals, processes, and modeling. Walter de GruyterGgmbh, Berlin, $\mathrm{p} 1$

Xavier AM, Logeswari A, Mano S (2013) Removal of chromium from real tannery effluent by using bioadsorbents. Int J Eng Sci 2(7):2278-4721

Yamamoto K, Win KM (1991) Tannery wastewater treatment using a sequencing batch membrane reactor. Water Sci Technol 23(7-9): 1639-1648

Yasmeen S, Kabiraz M, Saha B, Qadir M, Gafur M, Masum S (2016) Chromium (VI) ions removal from tannery effluent using chitosan-microcrystalline cellulose composite as adsorbent. Int Res J Pure Appl Chem 10(4):1-14

Publisher's Note Springer Nature remains neutral with regard to jurisdictional claims in published maps and institutional affiliations. 